\title{
Grey zones of production: Discussing the technology of tools at the Lojanik quarry in west-central Serbia
}

\author{
Vera Bogosavljević Petrović ${ }^{1}$, Anđa Petrović ${ }^{2,3}$, Jovan Galfi ${ }^{2}$, \\ Divna Jovanović ${ }^{4}$, Đorđe Radonjić ${ }^{2}$ \\ 1. National Museum in Belgrade. Trg Republike 1a, Belgrade, Serbia. \\ Email: vbogosavljevicpetrovic@gmail.com \\ 2. University of Belgrade, Faculty of Philosophy, Department of Archaeology, Čika Ljubina 18-20, Belgrade, \\ Serbia. Email: Galfi: galfisha@ hotmail.com; Radonjić: djordjeradonjic@yahoo.com \\ 3. Sapienza University of Rome, Laboratory of Technological and Functional Analyses of Prehistoric Artefacts, \\ Piazzale Aldo Moro 5, 00136, Rome, Italy. Email: anda.petrovic@ uniroma1.it \\ 4. Geological Survey of Serbia, Rovinjska 12, Belgrade, Serbia. Email: djdivna@gmail.com
}

\begin{abstract}
:
Flaked stone artefacts found on the quarry Lojanik in west-central Serbia are good examples of how the function of non-diagnostic pieces could be determined through technological and use-wear analysis. In this study, we present the examples of surface clusters and artefacts from stratigraphic layers. Our attention is focused on the prevailing category of fragmented raw materials in the initial phase of knapping, preforms, debris, shattered pieces of anthropogenic origin and an immense number of artefacts and geofacts.

The study of mines and quarries, as well as distribution of the raw materials that come from the central Balkans is an understudied phenomenon. Flaked stone artefacts found on the outcrops of the Lojanik hilltop is a good example of how we can apply technological, petrological and use-wear analysis on this type of site. Keeping in mind the loose context of the finds, as well as the lack of any datable material, this issue has to be approached with a lot of caution, since the locality itself seems to show human presence during Palaeolithic, Neolithic and Chalcolithic. The main focus of the study was put on the prevailing categories linked to the initial extraction of raw material on the site, as well as initial steps of shaping the raw material into cores. Samples were collected from several outcrops and so-called workshops from two localities of the hilltop: Lojanik 1 and Lojanik 2. The focal points of interest are categories that include waste, shatter, technical or shaping flakes. Worked pieces of raw material are now in the central position, and the study of these pieces have opened new grounds for this and similar occurrences - the study of so-called "grey zones" of production.
\end{abstract}

Keywords: raw material; quarrying; PDSM analysis; microwear analysis; Palaeolithic; Neolithic; Chalcolithic; central Balkans

Published by the School of History, Classics and Archaeology, University of Edinburgh ISSN: 2055-0472. URL: http://journals.ed.ac.uk/lithicstudies/

Except where otherwise noted, this work is licensed under a CC BY 4.0 licence. 


\section{Introduction}

Particularly important period in the study of chipped stone technology in Serbia is the first decade of this century when the systematic approach to the petroarchaeological studies has been introduced, that is, when a question of provenance was incorporated as an inseparable element of the lithic studies. Before 1990, only three sites were known in Serbia as potential mines of the stone raw materials: Ramaća in central Serbia (Jovanović \& Milić 1988), Kremenac in the east Serbia (Šarić 2013) and Lojanik in the west-central Serbia (Bogosavljević Petrović et al. 2017). Such a situation illustrates the full amount of circumstances and the absence of more compelling interest for studying lithic mining activities. When identifying the location of the extraction of raw materials and the relationship with the closest settlements, the specific academic goal has been significantly changed, which is well illustrated in case of the quarry Lojanik, and the Early Neolithic site Crkvine, as well as the Late Neolithic and Chalcolithic site Divlje Polje (Bogosavljević Petrović et al. 2017).

The fact that $80 \%$ of raw materials from the nearby Early Neolithic settlement Crkvine come from Lojanik and the case that surface concentrations both on the settlement and on the quarry are of Palaeolithic provenance with the same raw material structure are the main reasons for taking interest in Lojanik. This information has turned the focus of the research to the study of the distribution of raw material coming from the outcrops of Lojanik though different time periods on the wider area of the central Balkans (Bogosavljević Petrović \& Starović 2016: 35, fig. 11). The main methodological issues are concerned with the secondary context noted on the slopes of the Lojanik hill and the problems of defining the extraction and production areas that are in the vicinity of the outcrop zones.

\subsection{Geography and geology}

The site of Lojanik (N $43^{0} 41^{\prime} 12^{\prime \prime}$; E $20^{\circ} 37^{\prime} 07^{\prime \prime}$ ) is a hilltop located in west-central Serbia on the right bank of the Ibar River (Figure 1), roughly $10 \mathrm{~km}$ south from its confluence with West Morava River. The Ibar River presents an important route since it connects wide areas of modern day Serbia. This notion is backed by the early human presence in the area (Bogosavljević Petrović \& Marković 2014; Mihailović \& Bogosavljević Petrović 2009; Mihailović et al. 2014). The relief diversity of this region is extremely pronounced with big rivers and their streams cut deeply into mountain massifs. The hilltop $(280 \mathrm{~m}$ above sea level), located in the vicinity of Mataruška Spa, is not very prominent in the landscape, and today it is mostly hidden by modern infrastructure, while the local population does not know a lot about the phenomena.

Geologically and geomorphologically, the site Lojanik is located on the border between the plains of Cačak-Kraljevo Neogene basin in the north and the northern segment of the Ibar ultramafic complex. It belongs to the geotectonic unit of the Western Belt, within the Vardar Zone (Karamata et al. 2000). Dominant are peridotites and serpentinites of the Ibar ultramafic complex that probably sunk along the fault running in the west-south-west and east-south-east direction forming the Kraljevo Tertiary basin. Deposited over them are Tertiary limnic sediments (Marković et al. 1963). It is assumed that occurrence of the thermo-mineral water in Mataruška Spa in the immediate vicinity of Lojanik could be related to the same faults. In the later geological epochs (Pliocene, Quaternary) the old tectonic structure was remodeled by latter faults (Figure 2). Still, Čačak-Kraljevo depression reveals a tendency to sink. On the basis of hydrogeological investigations, it has been concluded that the geothermal anomaly in Mataruška Spa resulted from intensive volcanic and intrusive magmatic activity, which developed during the Tertiary in the area more to the north in the Kotlenik Mt. as hydrothermally altered rocks, propylitic dacites, andesites, and their tuffs have been encountered by deep drilling (Protić 1995). 


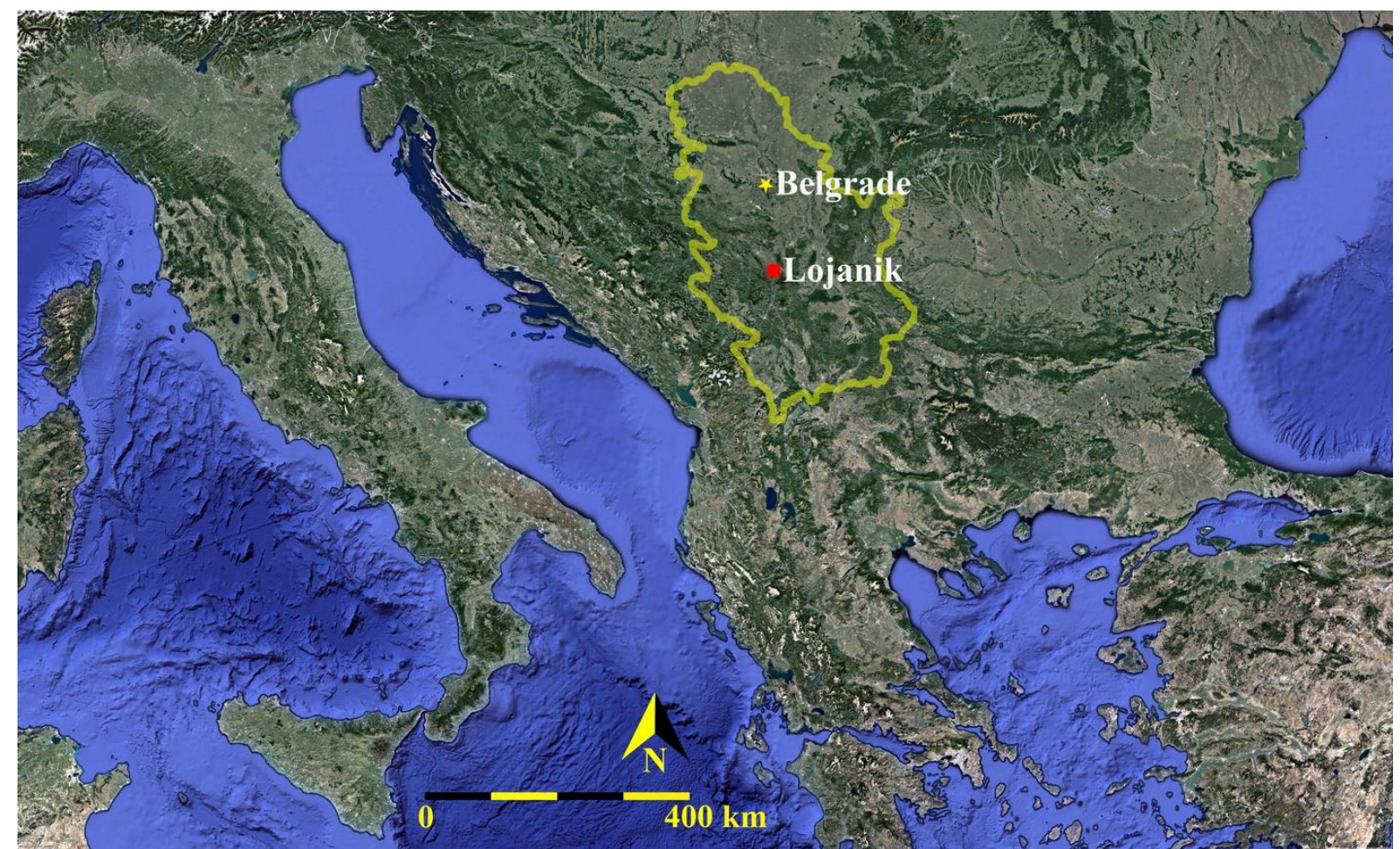

Figure 1. Position of the Lojanik quarry within a wider area. (From Google Earth).

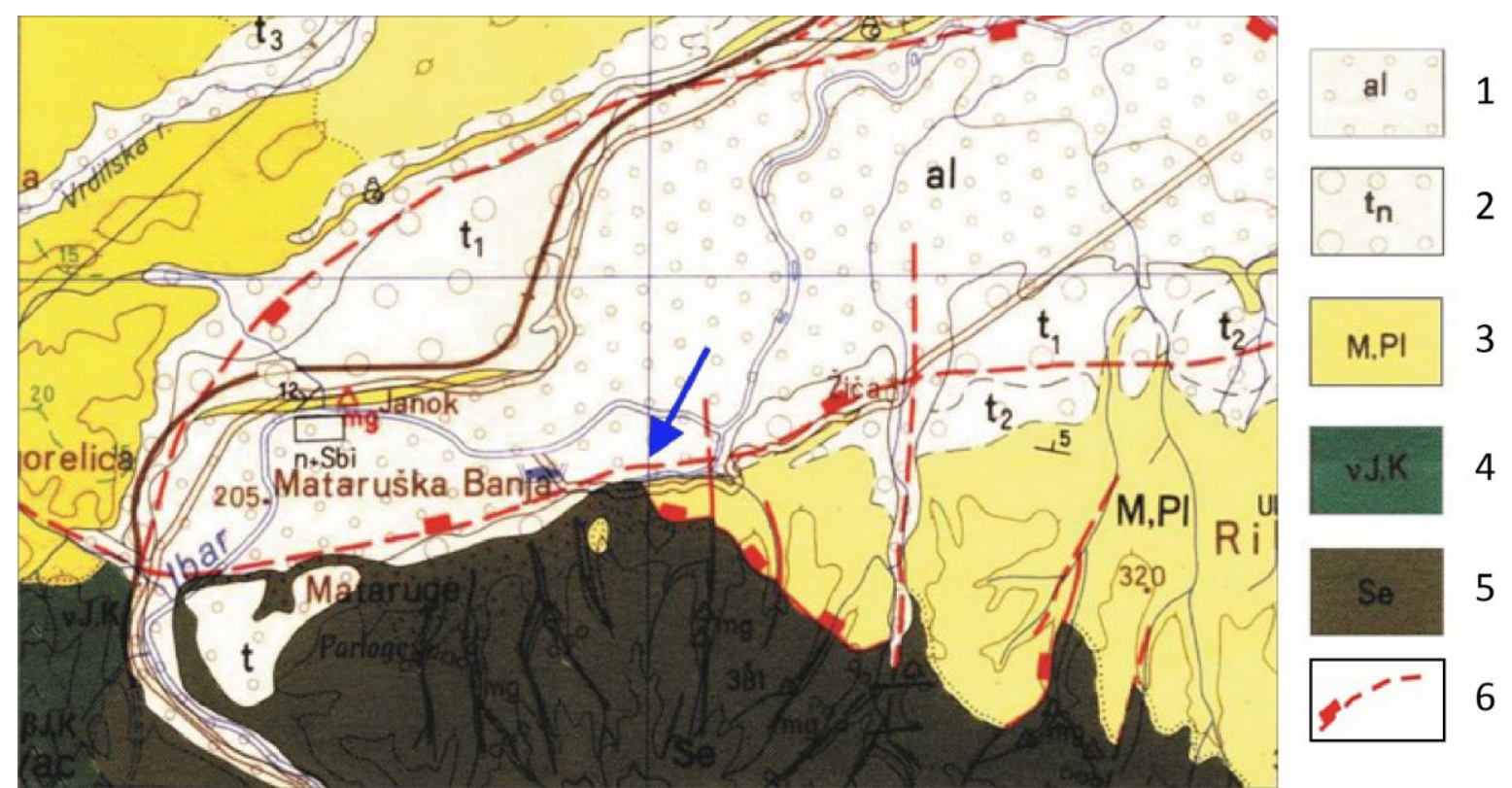

Figure 2. Basic Geological Map of Kraljevo City, 1:100 000 - an excision (after Marković et al. 1963); Blue arrow is showing Lojanik hill: 1. alluvium; 2. river terraces; 3. clastites, limestones, clays with coal (Pannonian and Pontian); 4. gabbros; 5. serpentinized peridotites; 6. faults.

Written records by Serbian geologists about the petrified forest and trees at Lojanik are rare. While studying sediments of the Miocene age in the Kraljevo depression P. Stevanović (1977) noticed the remains of "silicified trunks of coniferous and deciduous origin in the profile of Miocene conglomerates with petrified wood" (Pavlović, Stevanović \& Eremija 1977: 273). After that, there was no synthetic study until the year 2014 (Marinčić 2014). A proposal for protection of Lojanik as a nature park was suggested as part of the archaeological investigation project of ancient mining (Bogosavljević Petrović et al. 2017: 24, 25). 
The origin of silica is interesting from a geological aspect but the process of transformation of organic material of wood into silica was of interest for the biologists who made the first X-ray analyses of petrified trees at the end of the $20^{\text {th }}$ century and tried to explain the transition mechanism of organic into inorganic (siliceous) material. Until a few years ago, the prevailing opinion was that typically, the silicified trees were oak. Most recent analyses of silicified wood from Lojanik revealed organogenic structure consisting of opal, chalcedony and minimal amount of clay. Anatomic structures correspond to that of conifers, fir tree (Abies) (Joksimović et al. 1977), and thus the initial identification of oak was refuted.

\subsection{Short history of research}

The hill was visited by our team for the first time during 1989, when it was registered as an archaeological place of geoheritage. After that, successive short visits with limited scope of observation were the only source of archaeological investigation for a long time until the end of 2015 when a topic-oriented survey was performed (Bogosavljević Petrović et al. 2017: 21-24). Surface concentrations of artefacts dispersed across the slope of Lojanik 1, on the right side of the Kremenjak Stream, are placed around angular opal-rich rocks, which are suitable for raw material extraction that was preliminary shaped in situ. This debitage has allowed the initial study of the technological phases of reduction during the 2016. campaign (Figure 3). The study has generated questions about the manner of raw material extraction, as well as the time periods during which it had been used (Bogosavljević Petrović et al. 2016: 17; 2017). This has made space for analysis of the technological traits, alterations on the material itself and the stages of reduction detected on worked pieces of raw material. During the 2016 campaign, the field work was mostly focused on documenting the existing situation, through orthophotogrammetric plans and 3D scanning of the surface collections on the location of Lojanik 1.

During the 2017 campaign, we have turned our attention to the locality of Lojanik 2, where a slope on the west side of the Kremenjak Stream, was tested with several trenches (A, $\mathrm{B}, \mathrm{C})$. All of that sum up to seven clusters of raw material outcrops on the slopes of Lojanik 1 , Lojanik 2, as well as recent and authentic exploitation of the opal, around and in the bedrock and Kremenjak stream channel (Figure 4).

\section{4. Problems}

During the technological and typological analysis, one group of artefacts has started to become more and more distinguished from the rest. This group has failed to meet the criteria of an artefact, geofact or an extracted piece of raw material. This is partially due to the physical traits of the raw material and not enough petrological as well as archeological study. An understanding of this "grey zone" classification has become our main research objective and will be presented through a sequence of analytical procedures discussed further in the text of the paper. At the Cluster 1 local, preliminary analysis has indicated a raw material, products of initial knapping and waste products as main characteristics of the location (Figure 5).

The concentration of hammerstones in the south part has suggested a workshop area where production has occurred, and where pieces of raw material were prepared for the next stage (Figure 6).

At Lojanik 2 (Slope 1), the outcrops were excavated by trenches and authentic types of extraction of opals and silicified wood were noted (Figure 7). The extraction zones had presence of sharp pieces of discarded walls offspring with one obvious goal of exploitation an opal in homogeneous appearance (Figure 8). During the excavations the effect of atmospheric agents was discovered very soon, after the first layers of soil. 


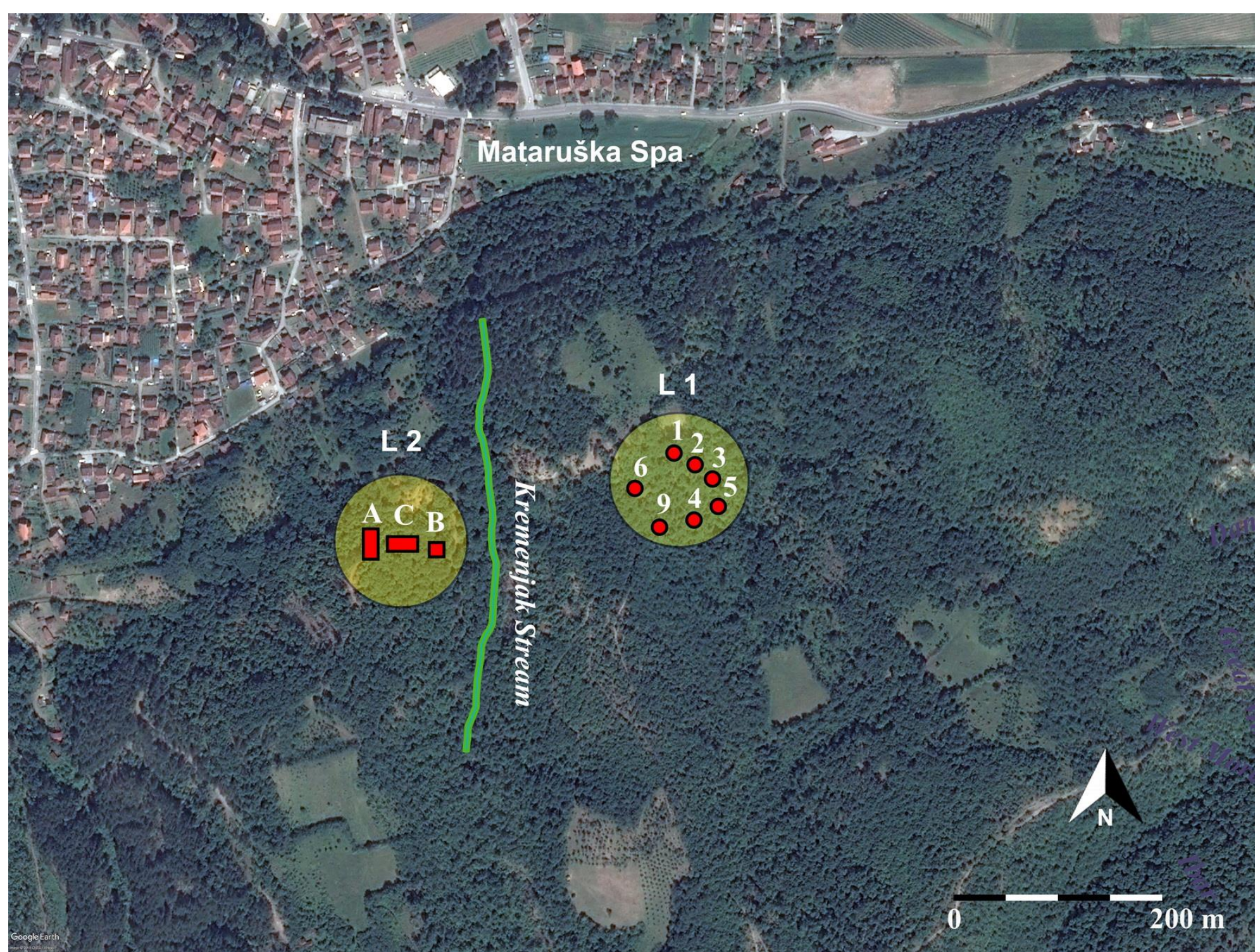

Figure 3. Two zones of archaeological excavation: Lojanik 1 (surface clusters) and Lojanik 2 (Slope 1 with the position of trenches). (From Google Earth). 

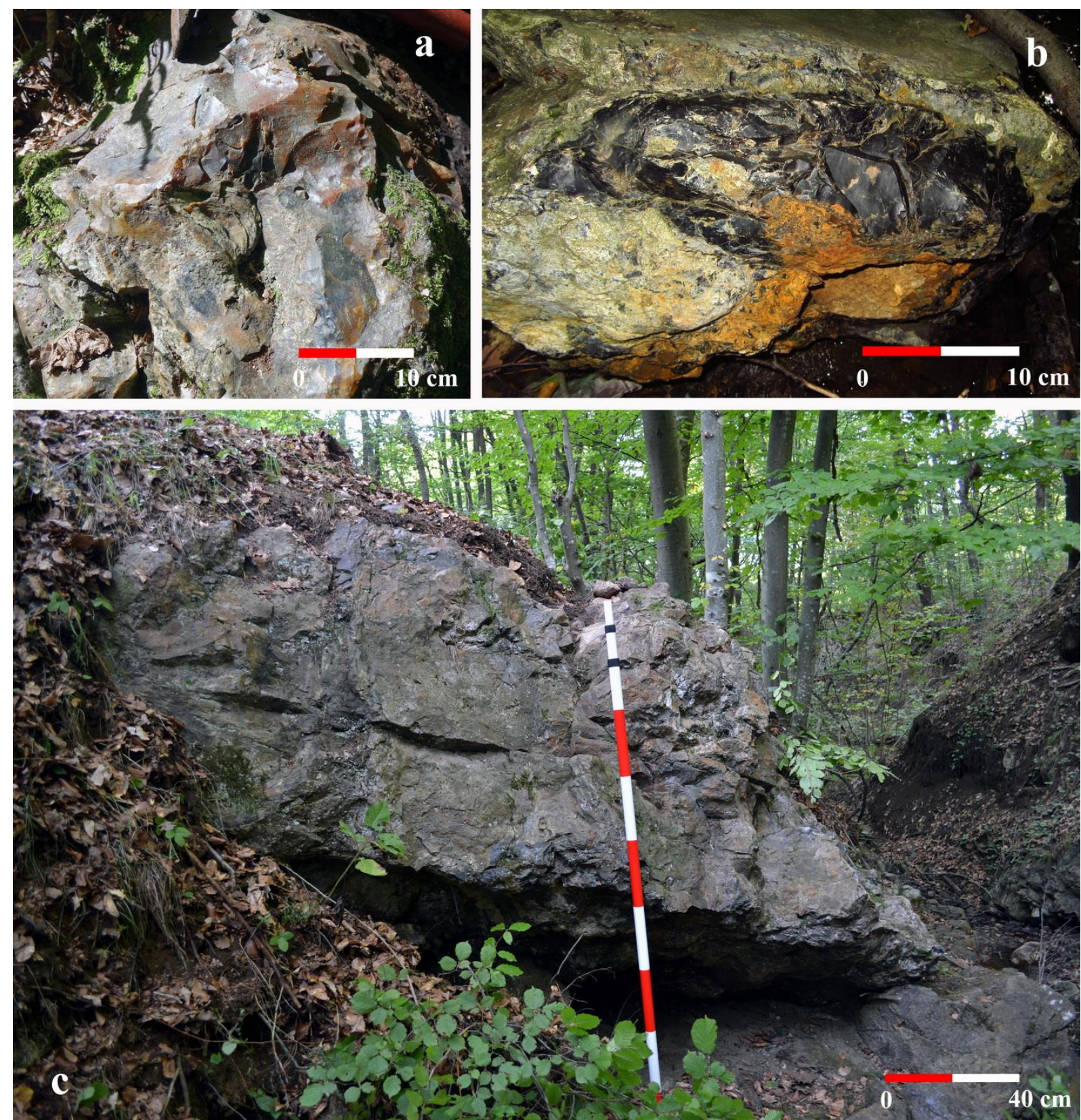

Figure 4. Kremenjak Stream: a) traces of exploitation (detail); b) example of black opal extraction; c) rock of opal in the stream channel. 


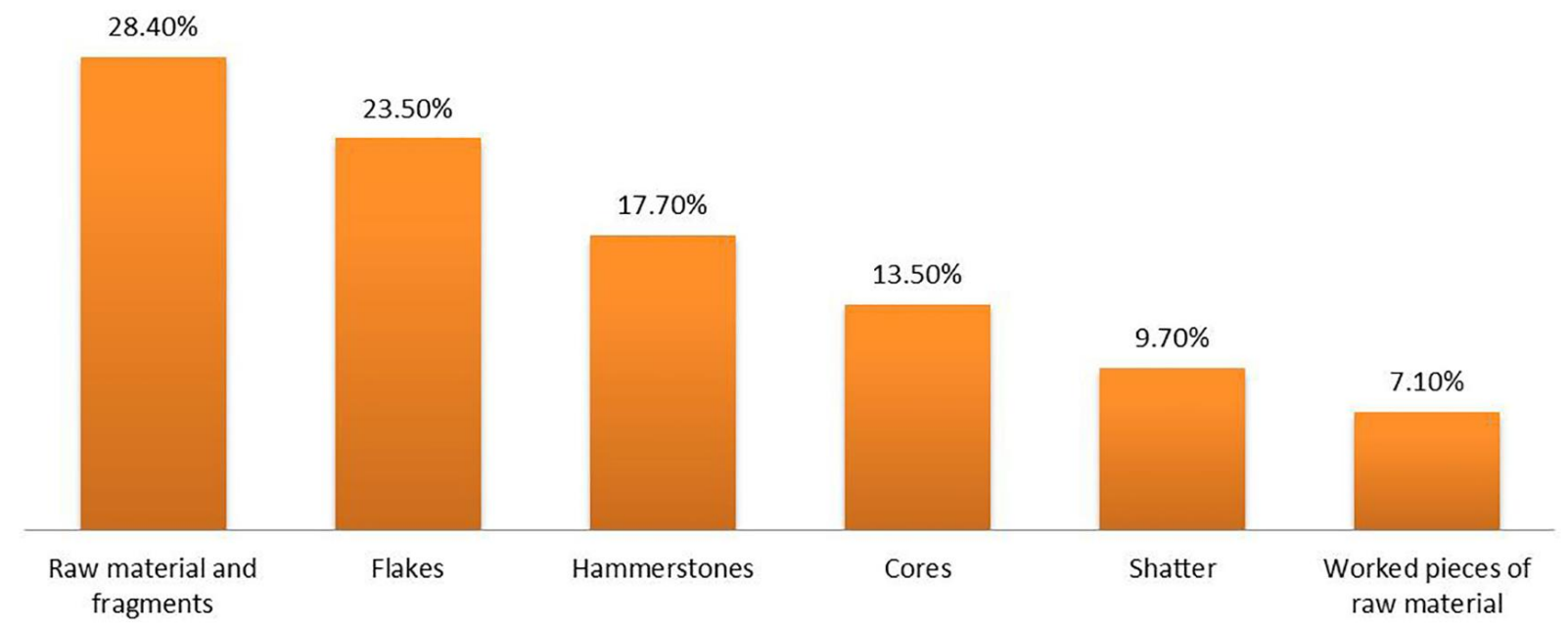

Figure 5. General structure of Cluster 1 (Lojanik 1).

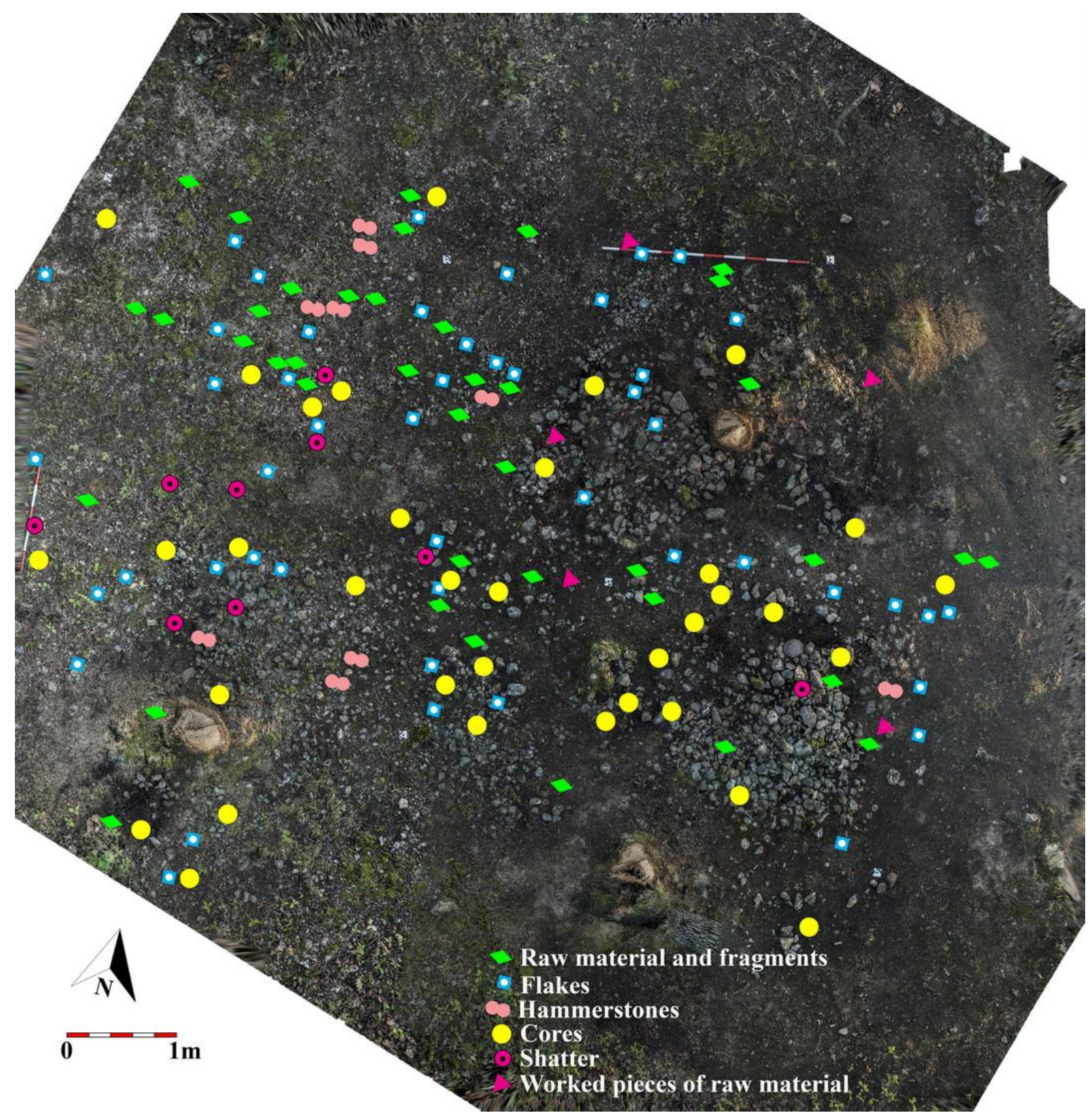

Figure 6. Cluster 1: Orthophoto with spatial distribution of main types of artefacts. 

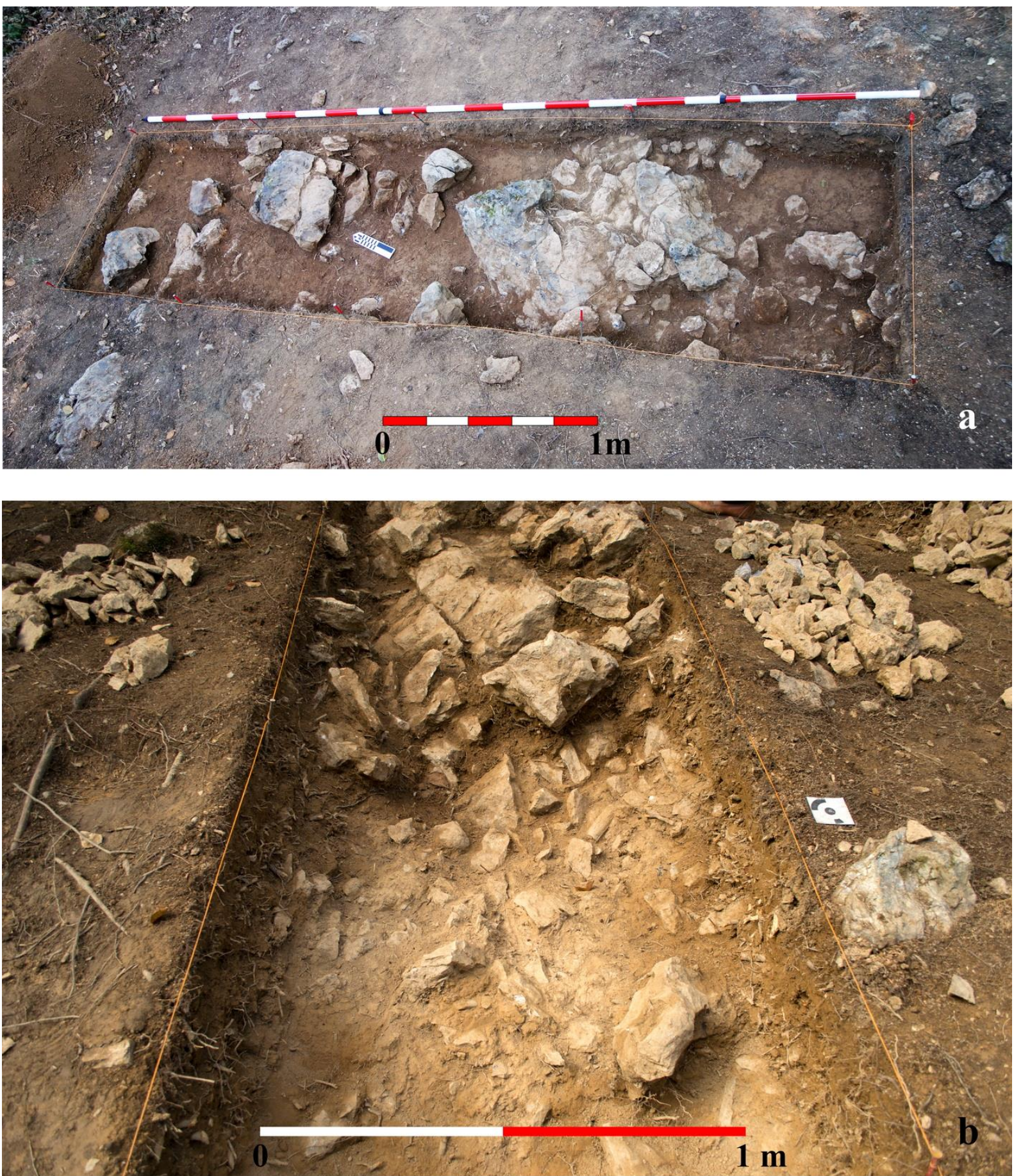

Figure 7. Lojanik 2: a) trench A; b) trench C, squares VI, VII, VIII.

One of the applied technological modes of extraction was separation of massive pieces of raw material from a larger rock to shape precores. Edges were corrected by separating long and massive crested blades. Solid and plain platforms are represented on massive flakes. These are the stages of preparation of the precores, whose wastes are differentiated according to the technological trace from Lojanik 2 . The products of flaking, primarily crested blades seem archaic and unregulated in relation to the later phases of the lithic organization (Figure 9).

The aim of this small and quantitively very limited study was to discover how the application of use-wear methodology with technological and petrological analysis on material coming from a quarry site can improve our technological knowledge, mark all the processes 
that affected the chipped stone finds, and help us understand the site formation in a better fashion.

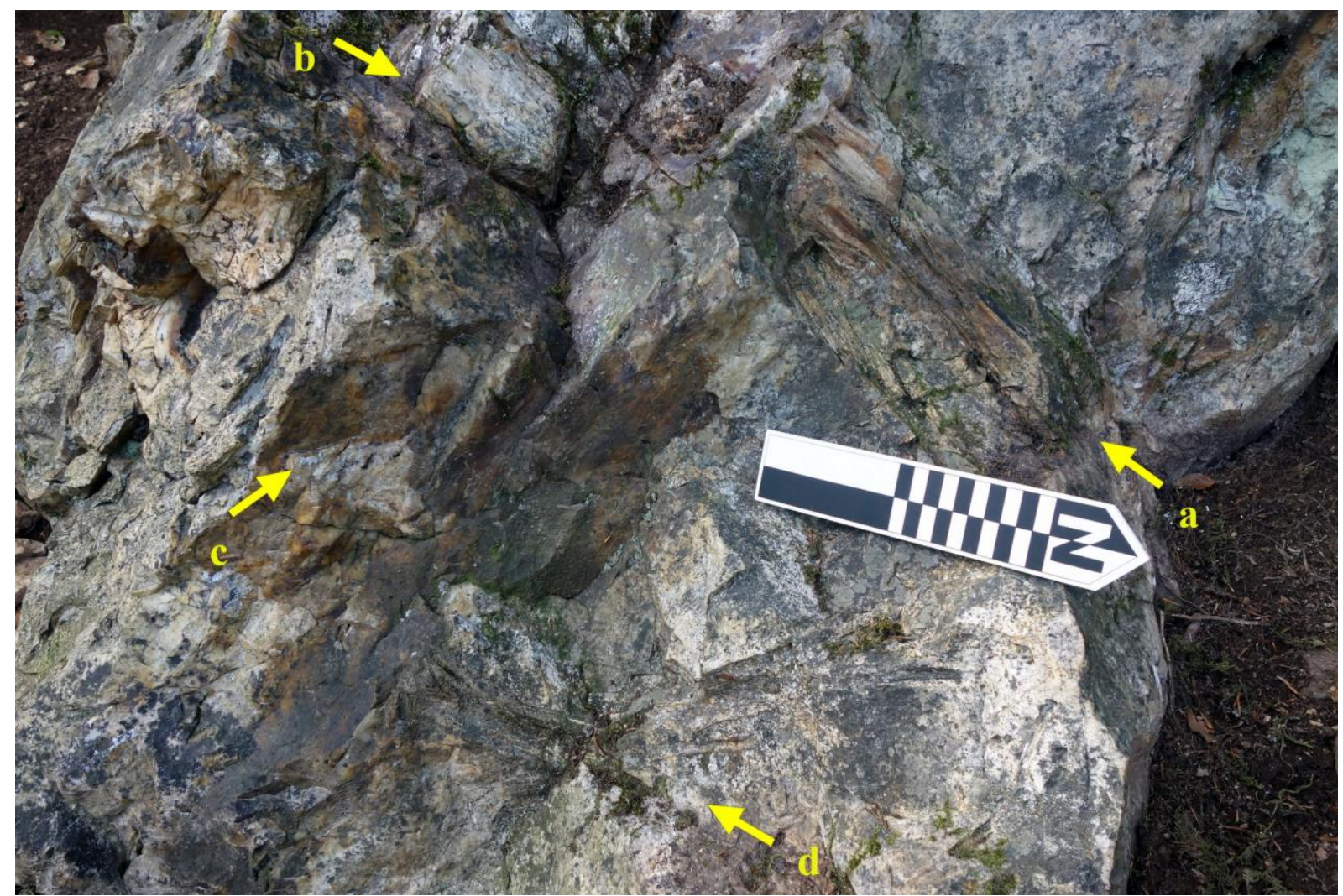

Figure 8. Lojanik 2, trench C: a) extracted tree branch; b) part of branch in situ; c) traces of the opal extraction process; d) negative of extracted part of tree. Scale in centimetres.
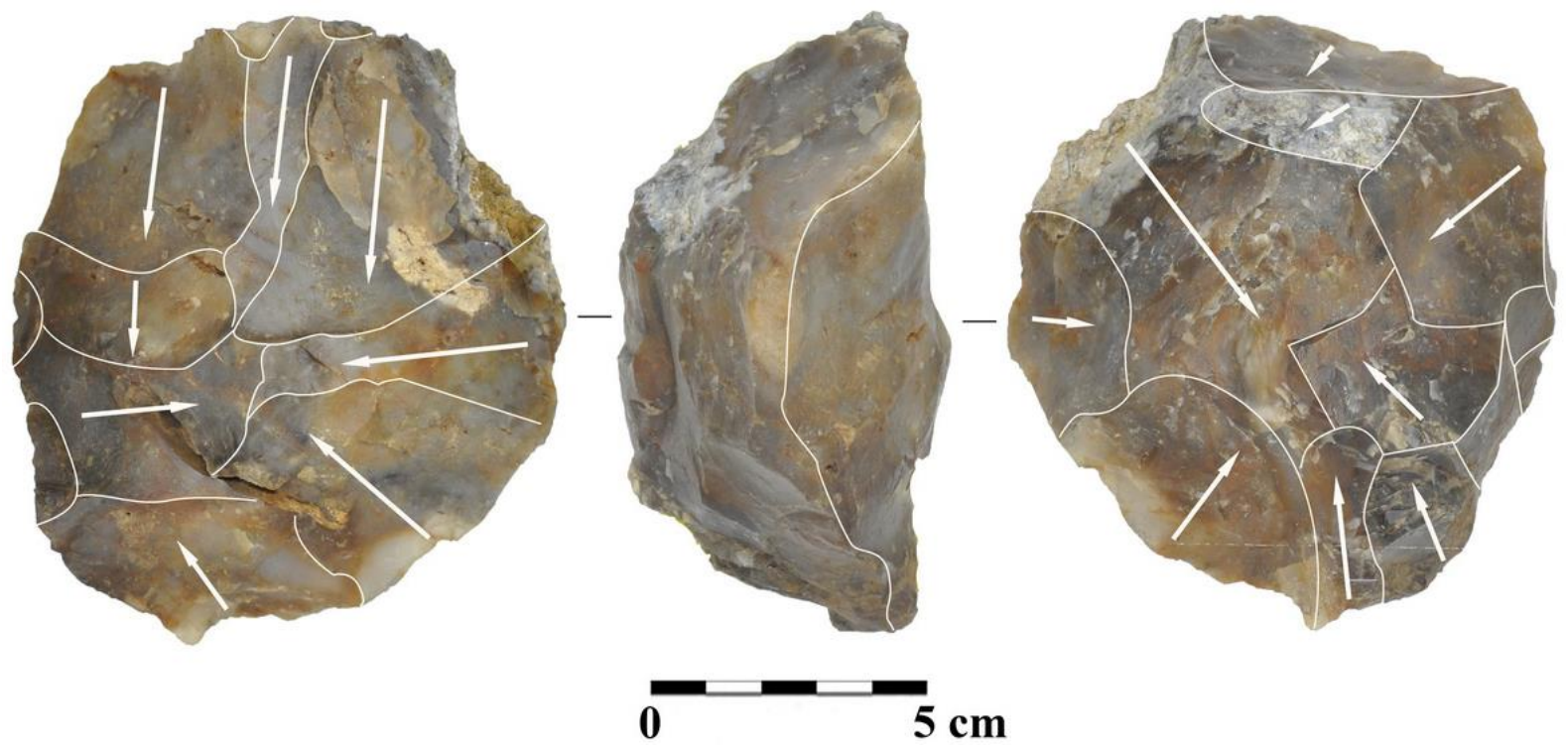

Figure 9. Lojanik 2, centripetal levallois core.

\section{Sample and method}

The sample presented here is made with the intent of showing types of damage on artefacts, insufficiently expressed traces of human activities, or intense traces of natural effects which can interfere with our judgment. Surface finds from the Clusters 1-5 (Lojanik 1) 
with whole assemblage from Slope 1 (Lojanik 2) were preliminarily observed, and this adds up to about 5000 artefacts (Figure 3). Table 1 presents the basic data of the surface samples of Cluster 1 and Slope 1 with the samples from stratified contexts of trenches B and C. Out of this large assembly, 39 groups of samples have been singled out, and they come from 63 artefacts. The pieces have been analysed from a macroscopic point of view with petrological observations (Figure 10, 11, 12), as well as typological, technological and microwear analysis. Furthermore, examples of experimental knapping have been proposed as one of the controlling agents for the determination of use-wear on the artefacts.

Table 1: List of samples.

\begin{tabular}{|c|c|c|c|}
\hline Sample & Site & Cluster & Preliminary classification \\
\hline 1 & Lojanik 1 & 1 & Precore \\
\hline 2 & Lojanik 1 & I & Core \\
\hline 3 & Lojanik 1 & 1 & Worked piece of raw material \\
\hline 4 & Lojanik 1 & 1 & Fragment of raw material \\
\hline 5 & Lojanik 1 & I & Fragment of a raw material \\
\hline 6 & Lojanik 1 & 1 & Flake \\
\hline 7 & Lojanik 1 & 1 & Flake \\
\hline 8 & Lojanik 1 & I & Hammerstone fragment, test piece \\
\hline 9 & Lojanik 1 & 1 & Fragment of raw material \\
\hline 10 & Lojanik 1 & 1 & Chunk \\
\hline 11 & Lojanik 1 & I & Worked piece of raw material \\
\hline 12 & Lojanik 1 & 1 & Massive flake \\
\hline 13 & Lojanik 1 & 1 & Fragment of a raw material \\
\hline 14 & Lojanik 1 & I & Worked piece of raw material \\
\hline 15 & Lojanik 1 & 1 & Worked piece of raw material \\
\hline 16 & Lojanik 1 & 1 & Core \\
\hline 17 & Lojanik 1 & I & Massive flake \\
\hline 18 & Lojanik 1 & 1 & Hammerstone \\
\hline 19 & Lojanik 1 & 1 & Geofact \\
\hline 20 & Lojanik 1 & I & Geofact \\
\hline 21 & Lojanik 1 & 1 & Retouched blade \\
\hline 22 & Lojanik 2 & Slope $1 / a$ & Flake \\
\hline 23 & Lojanik 2 & Slope $1 / b$ & Blank for scraper \\
\hline 24 & Lojanik 2 & Slope $1 / b$ & Flake \\
\hline 25 & Lojanik 2 & Slope $1 / b$ & Massive flake \\
\hline 26 & Lojanik 2 & Slope $1 / b$ & Flakes (2) \\
\hline 27 & Lojanik 2 & Slope $1 / b$ & Blank for scraper \\
\hline 28 & Lojanik 2 & Slope $1 / b$ & Fragmented flake \\
\hline 29 & Lojanik 2 & Slope $1 / b$ & Pointed distal fragment \\
\hline 30 & Lojanik 2 & Slope $1 / b$ & Massive blank for scraper \\
\hline 31 & Lojanik 2 & Slope $1 / b$ & Flake \\
\hline 32 & Lojanik 2 & Trench B, square X, split 2 & Flake \\
\hline 33 & Lojanik 2 & Trench B, square XII, split 1 & Flakes \\
\hline 34 & Lojanik 2 & Trench B, square XII, split 3 & Flakes (5) \\
\hline 35 & Lojanik 2 & Trench B, square XIII, split 3 & Blade (3) \\
\hline 36 & Lojanik 2 & Trench C, square VIII, split 1 & Tool fragments (2) \\
\hline 37 & Lojanik 2 & Trench C, square VIII, split 5 & Flakes, blade ( 6 artefacts) \\
\hline 38 & Lojanik 2 & Experiment 1 & Products of knapping - part (4) \\
\hline 39 & Lojanik 2 & Experiment 2 & Products of knapping - part (8) \\
\hline
\end{tabular}



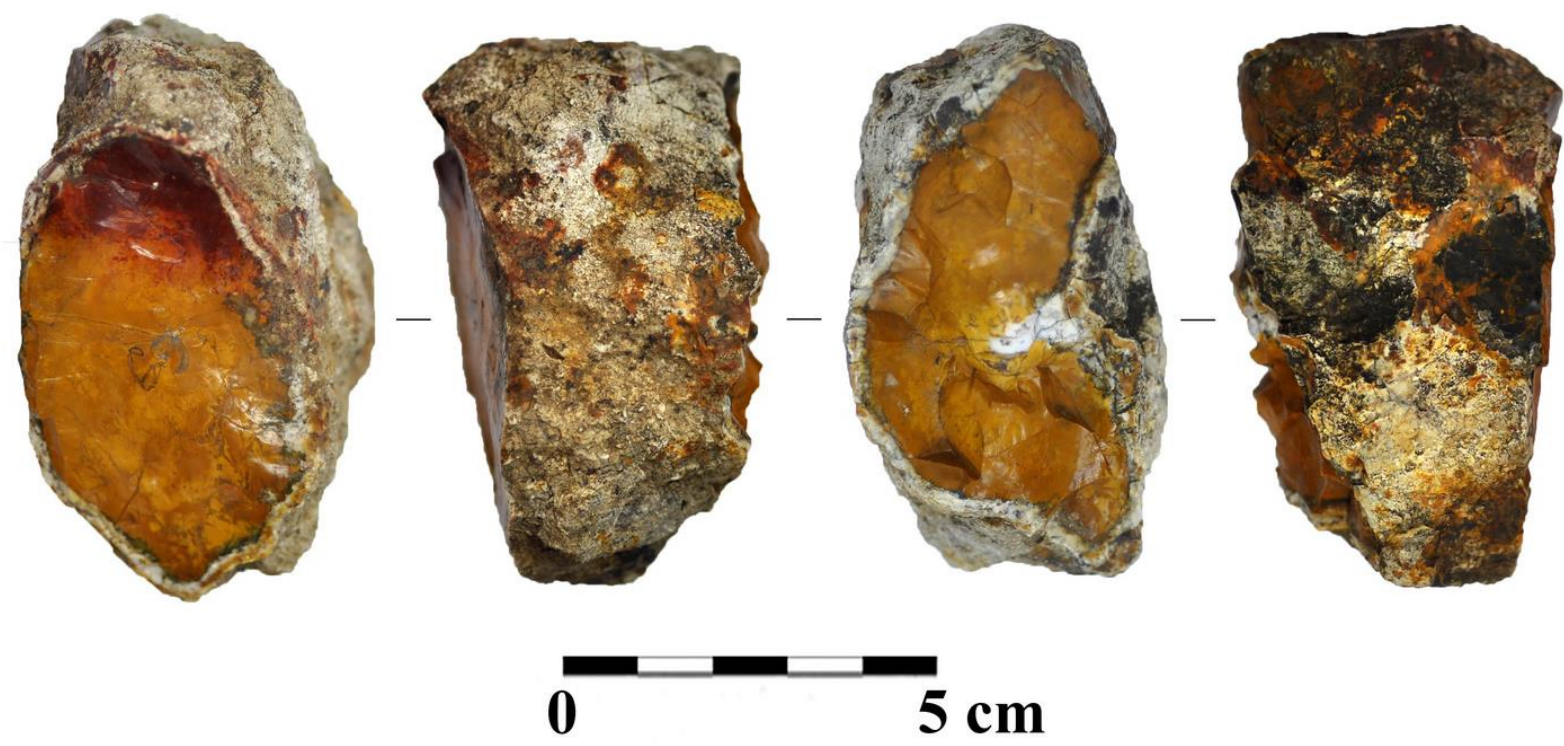

Figure 10. Lojanik 1, Cluster 1: sample 13, part of raw material from primary deposit.

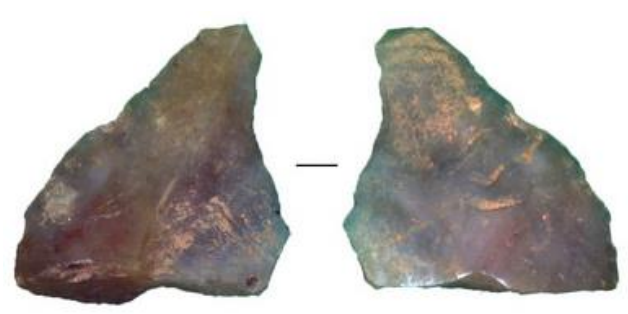

a

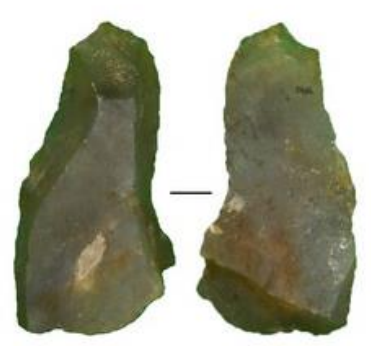

b

0

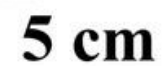

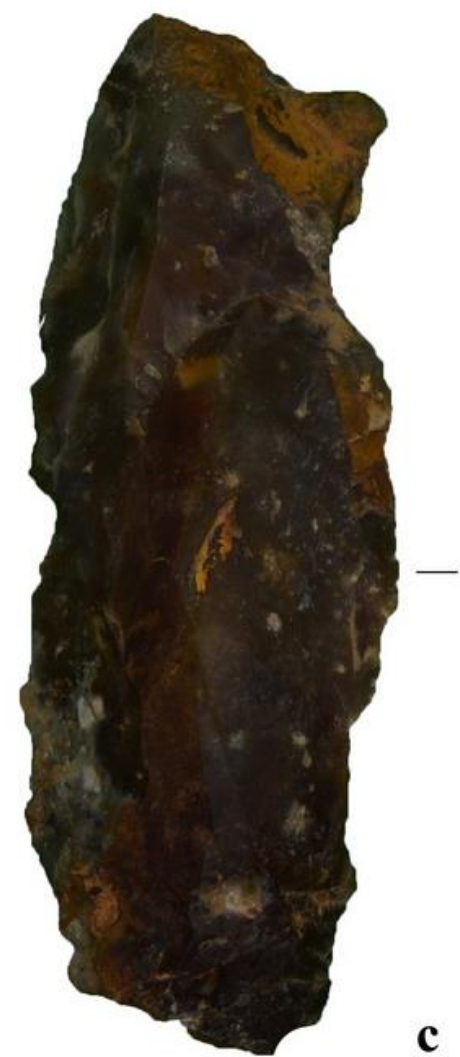

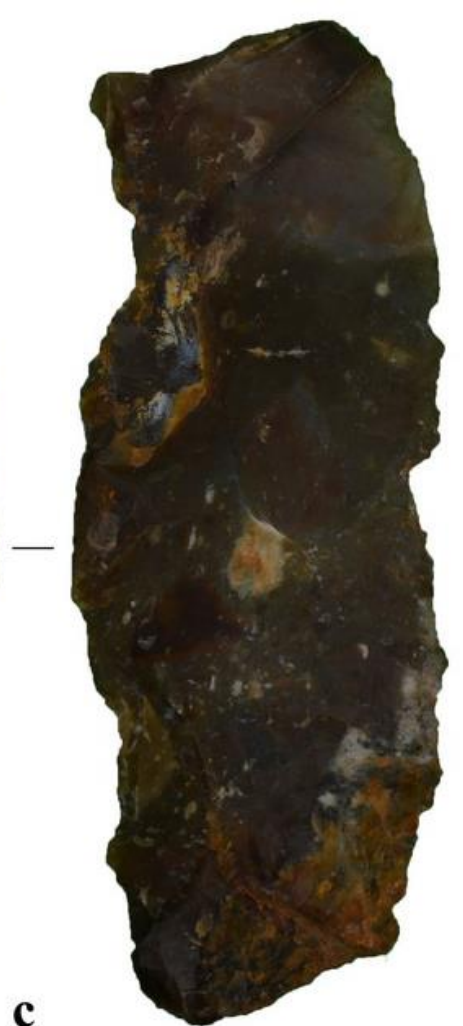

Figure 11. Lojanik 2, samples of raw material: a, b (trench C, square VIII, split 1) flakes; c (trench B, square XIII, split 3) blade. 


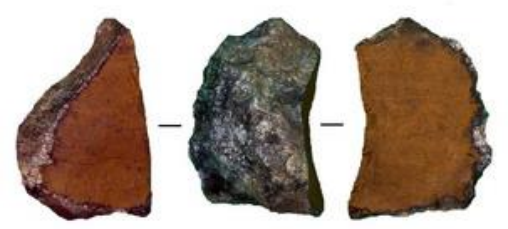

a

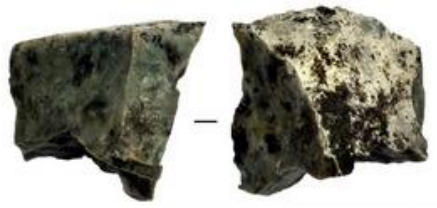

b

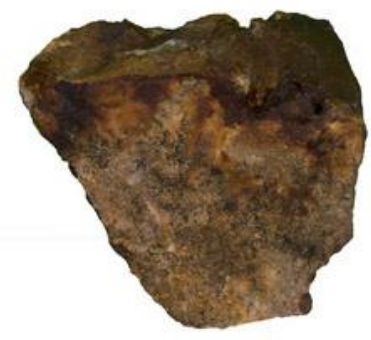

c

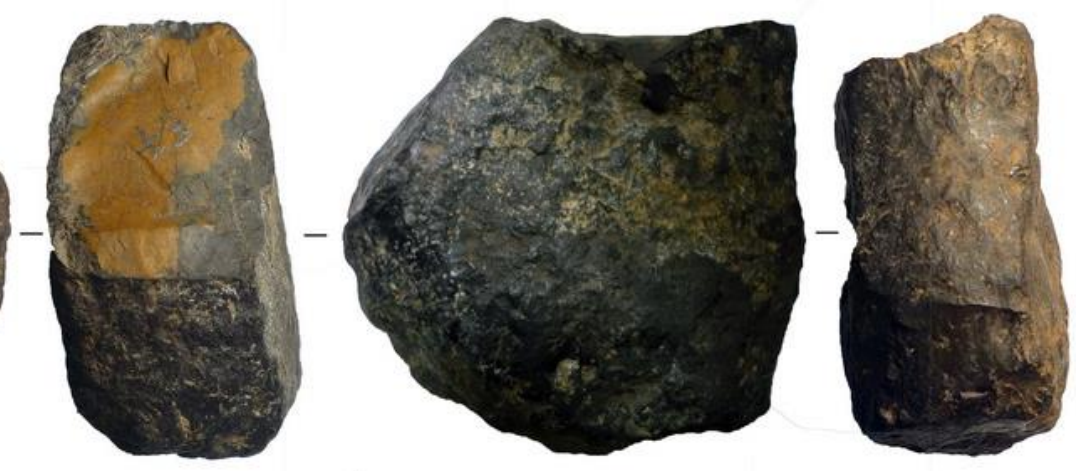

d

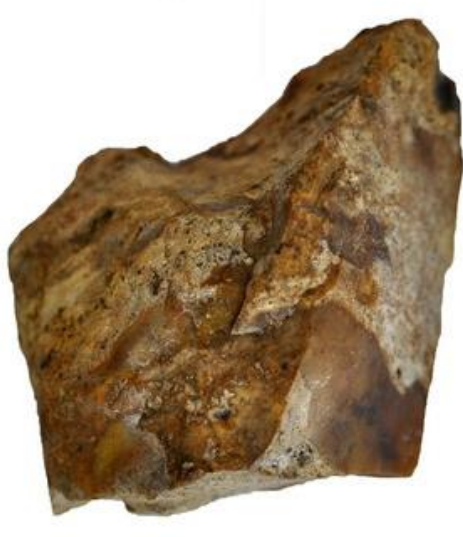

f

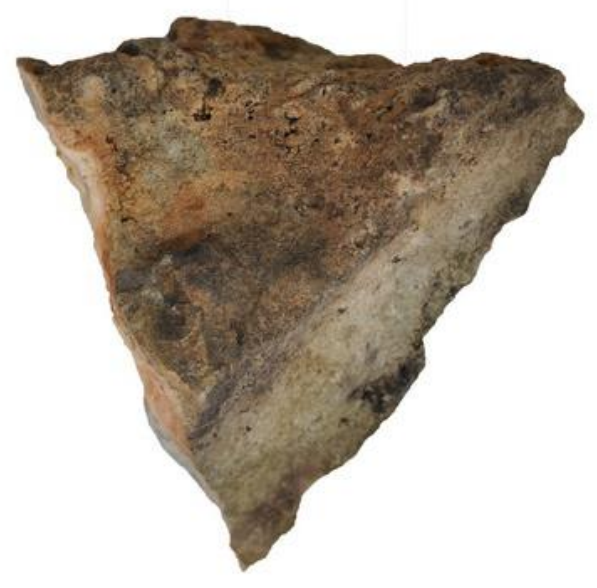

g
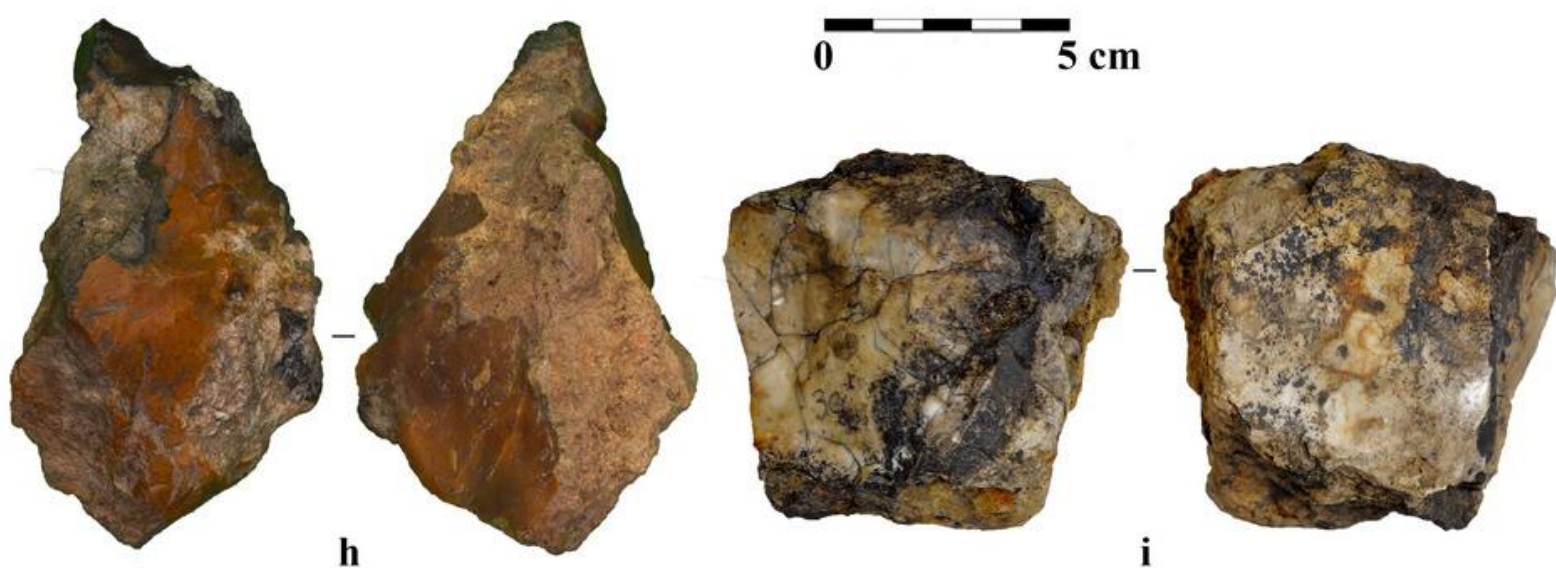

Figure 12. Lojanik 1, pieces of raw material, and artefacts: a) sample 5; b) sample 10; c) sample 17; d) sample 8; e) sample 11 ; f) sample 3 ; g) sample 20 ; h) sample 1 ; i) sample 14 . See Table 1. 
From the point of microwear analysis it is almost impossible to apply the use-wear analysis of whole assemblages and in most cases sampling is necessary. Important parameters as context, dating, spatial position and type of artefacts are considered. Having in mind site stratigraphy and geological setting, as well as the specific nature of the site it is quite difficult to distinguish the sample by context. But, for the purposes of our work and for marking all the processes that affected the chipped stone artefacts from Lojanik site we choose to sample three groups. All of these groups are already mentioned above but further reasoning of the chosen artefacts for application of use-wear methodology is needed.

There were few reasons to apply the traceological methodology in the case of quarrying at Lojanik. The first one is directly connected to the problem of secondary context and colluvial movement of the soil: noting and recording the post-depositional surface modifications (PDSM) on the chipped stone artefacts. Keeley warns about ignoring the naturally closed traces (Keeley 1980: 28-35), as many researchers afterwards have done (Gijn 1990; Glauberman \& Thorson 2012; Levi Sala 1986). PDSM is very helpful in any framework, and in our case it helps us to define the processes that affected the surface and preservation of the tools but also document the soil movement and other human or environmental impacts like trampling and mechanical movement. The second reason is to better determine the applied technology, since as previously said a lot of artefacts found on Lojanik are in various stages of production and the sites have been occupied in various prehistorical periods in large timespan. The third reason to identify the possible use of some of the finished tools. This is probably the most questionable reason for conducting the usewear analysis on artefacts coming from a quarry site mainly because of their immense quantity and colluvial depositions, but it can also create new indications in interpreting this specific site and its activities. Also, these last results will not be discussed in this paper, because during the analysis it was noted that further sampling and analysis are necessary for more robust data.

The first group consisted of 14 pieces collected from surface layers and from Cluster 1 (Table 1, samples 5, 9, 13, 16, 21-31). Each piece has its own EDM number and it was mapped (Figure 6). The goal was to question all the post-depositional processes that affected these tools. The second group is represented by 17 artefacts coming from deeper layers from two of our trenches 2/1b, and 2/1c excavated in 2017 (Table 1, samples 32, 34-39). The third observed group is represented by experimental flakes made during the 2017 excavation season: one group of flakes and chips was made on whitish-grey opal (8 pieces) and slightly darker opal (4) (Figure 13). In total 43 pieces were analysed with both the low - and high power approach. This small sample represents just one part of the collected material but still indicates important data for future excavations and chipped stone processing.

Both low- and high-power approaches are implemented and the artefacts were examined in Laboratory Technological and Functional of Prehistoric Artefacts (LTFAPA) at the Sapienza University of Rome, using Stereomicroscope Nikon SMZ-U with reflected light (x 0.5 objective, $\mathrm{x} 10$ oculars, range of magnifications from $0.75 \mathrm{x}$ to $7.5 \mathrm{x}$ ) together with Toupview camera Software, Stereomicroscope Nikon SM2 745T (x10 oculars, range of magnifications $\mathrm{x} 0,67$ to $\mathrm{x} 5)$ together with a Nikon Digital Camera DXM1200 and Metallographic microscope Nikon Eclipse ME 600 (x5, x10, x20, x50, x100 objectives, x10 oculars) with transmitted and reflected light equipped with Differential Interference Contrast (DIC) and Confocal System. For microphotography a Digital Microscope Hirox RH 2000 was used. All the samples were previously washed during the deposition of material, with only warm water. Some pieces, when it was needed for micro observations, were washed with standard procedures in an Ultrasonic tank with demineralized water and Derquim soap for 1015 minutes and then 5-10 more minutes only in demineralized water. 

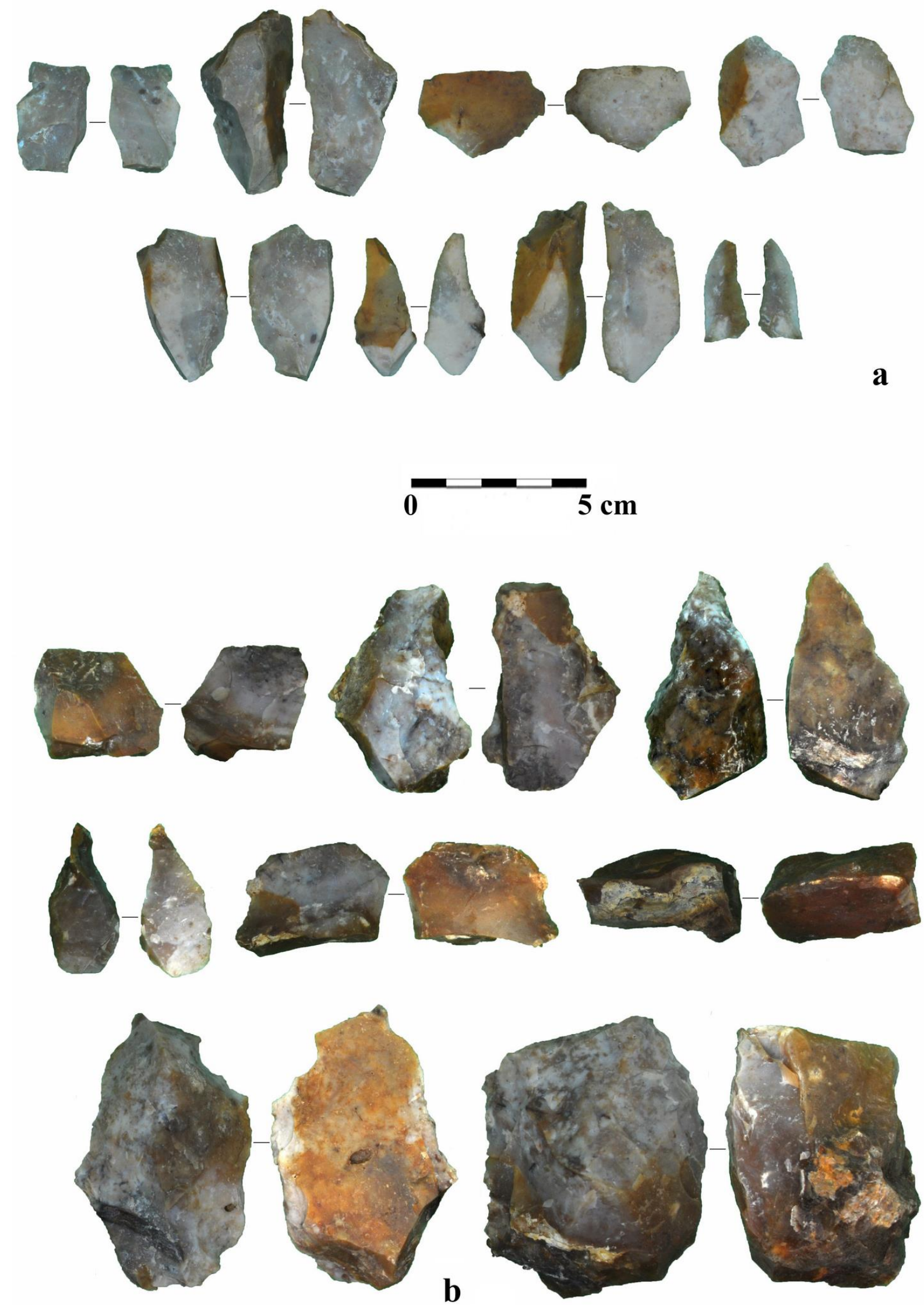

Figure 13. Experiment carried out by Jovan Galfi: a) whitish-grey part of opal; b) slightly darker part of opal. 


\section{Results}

All of the studied samples are basically silicified (cherts, opals, quartzites), and they present a group which is the most resistant to weathering. The most common alterations are caused by transport, and surface alterations created by weathering. The global category is dominated by examples from surface collections, which are in turn over $90 \%$ of the anthropogenic sample, i.e., fragmentation of bigger rock masses, and then transport as well as weathering (Figure $12 \mathrm{~h}$ ). The base result is that most of the sample presents a combination of different alterations, especially weathering and limited transport. A good example is presented by samples from the trenches, which are found in the layer.

The technological study of the material from Cluster 1 (Lojanik 1), has been done with the aim of understanding the reduction sequence and the activities conducted in this area. The composition of the sample (Figure 5), consisting of a high number of what can only be described as preforms, and a large number of massive hammerstones, leads us to assume that the area was used for extraction and primary reduction. The cores themselves are usually multi-platform and irregular, and most of them bear several flake removals. However, there are a couple of examples of cores in their advanced stages that are only used to produce flakes, and do not show any characteristic production technique. This, in combination with the lack of any diagnostic pieces prevents us from proposing any kind of chronology for this locality. However, a core found on the Slope 1 (Lojanik 2), can be a starting point for building a chronology for the wider area of Lojanik. The core (Figure 9), has an organized and a hierarchized flaking surface with defined convexities, which might correspond to the recurrent centripetal levallois technique (Levallois sensu Boëda 1993).

The first objective of the implementation of the microwear methodology on our sample is differentiation in cortex types. Cortex has commonly been used as an indicator of core reduction (e.g., Andrefsky 2005; Dibble et al. 2005), and the use of cortex amounts to identify production stage has increased in the last couple of decades as lithic analysts focused more on overall technology. This important parameter in analysis can be an indicator of both the reduction process and the development of patina. Therefore, the presence of chemical and mechanical alterations on chipped stone tools at the end of production helps us make behavioural inferences. A certain number of the artefacts recovered - mostly precores and blanks have coarse, primary cortex present (Figure 10), with the outer surfaces featuring both outcrop and transport weathering. Conversely, artefacts coming from trenches have a lighter cortex. The cortex varies from white to darker shades of orange to blue, as represented neocortex on the illustration (Figure 14).
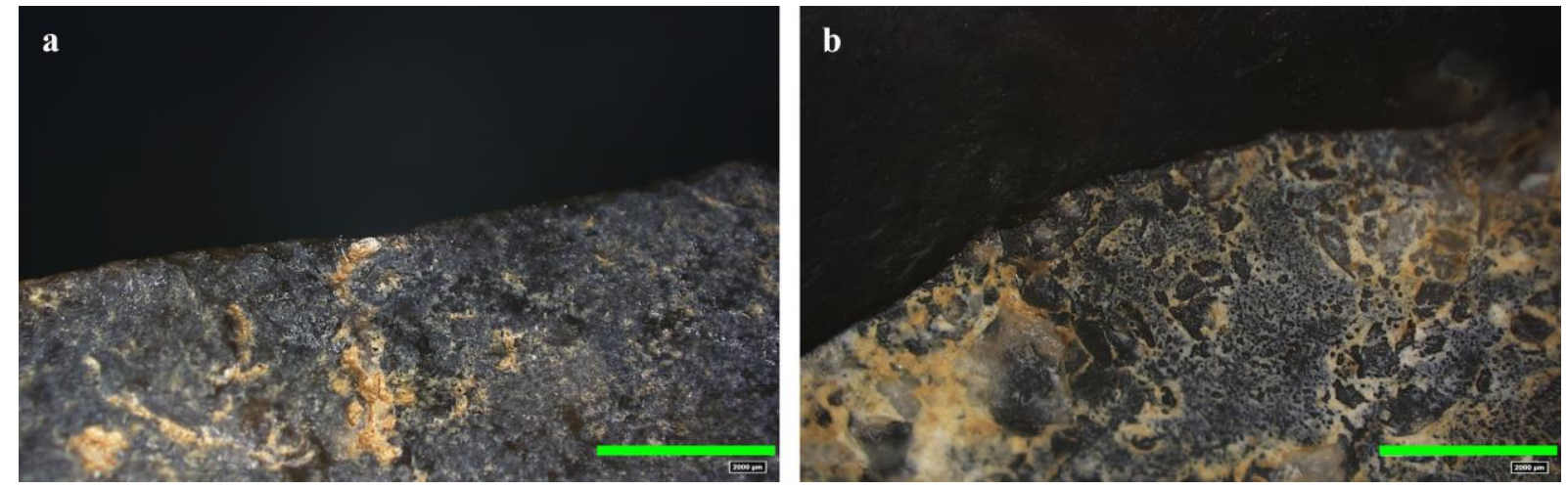

Figure 14. Different types of the cortex from trench B - neo cortex, represented with blue-orange-white film a) sample 34, blade; b) sample 32, flake, scale bar equal to $2000 \mu \mathrm{m}$

The second group of observations is focused on the patina formation. In this study, the already discussed, cortex on opal nodules are not considered to be a form of patina. We are 
limiting the term patina to the weathering on surfaces that have been indisputably worked by humans in prehistory. The majority of the tools were made on lighter coloured (beige and grey flakes and blades) pieces from Lojanik and are labelled as type 1 raw material in our internal classification (Bogosavljević Petrović \& Marković 2014: fig. 5; Bogosavljević Petrović et al. 2017: 36-37, fig. 14). These artefacts have a white patina (Figure 15) sometimes also presented on darker pieces as granular, chalky white coating with some cortex (Figure 16).
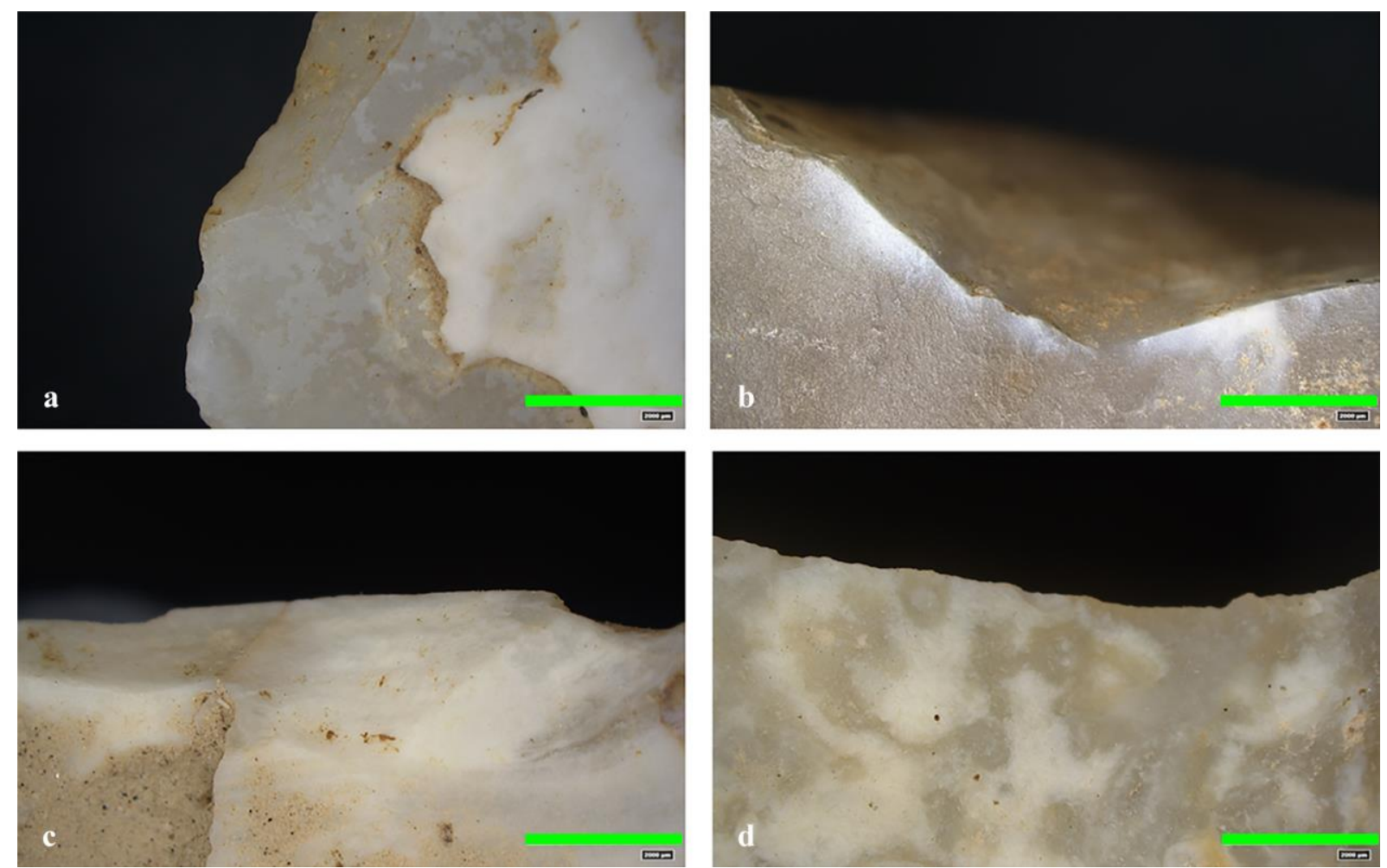

Figure 15. White patina formed on beige and grey flakes and blades (raw material type Lojanik 1): a) sample 37, flake; b) sample 36, flake; c) sample 37, flake, d) sample 37, blade, all from trench C, scale bar equal to 2000 $\mu \mathrm{m}$
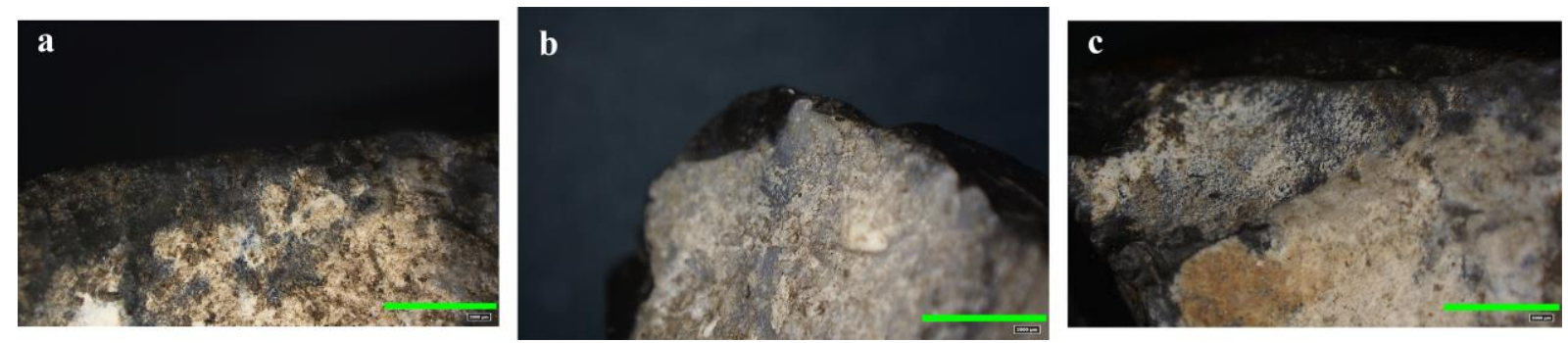

Figure 16. Chalky white patina and cortex on the retouched blade from Cluster 1, sample 21: a) lateral edge; b) distal dorsal end; c) proximal end close by lateral edge, scale bar equal to $2000 \mu \mathrm{m}$.

Some of the artefacts are covered with glossy patina as can be seen in Figure 10. There is no mention of how this glossy patina affects the use-wear results (Levi Sala 1986). Generally, it is considered to be a product of silica dessolution (Howard 2002). Stapert has distinguished between sheen (glossy patina) that as he says, it has been suggested that the patina variety originated from mechanical effects. However, most authors assume that the patina is a result of chemical processes in the soil (Stapert 1976: 12), and windgloss as he described as mechanically formed mainly as a result of polishing with chemical components that are part of the diagenetic process (Stapert 1976: 18). The same author concluded that even areas that 
are covered in glossy patina do not destroy potential polish or other use-wear traces. Experiments conducted by Levi Sala (1986) pointed out that the mentioned sheen develops faster on fine grained flint than on coarse grained flint, just as in our case.

The third group of observations is focused on the fact that the majority of analysed artefacts, coming from the excavated trenches have bright spots. The spots are described as smooth, highly reflective polish (gloss) on flint surfaces, occurring singly or in clusters. Most of the bright spots we observed are flat with and without striations. Previously bright spots were considered unexplained (Semenov 1964), or enigmatic (Vaughan 1981), or mysterious (Moss 1983). It was suggested after experimental work that bright spots are most probably created by frequent abrasion with other lithics or by soil abrasion. This is one of the mechanical alterations that are present on chipped stone tools from Lojanik where bright spots are present on edges, ridges and flat surfaces (Figure 17). Sometimes bright spots are mimicking the use-wear polish, but they are in most cases isolated, large and flat.
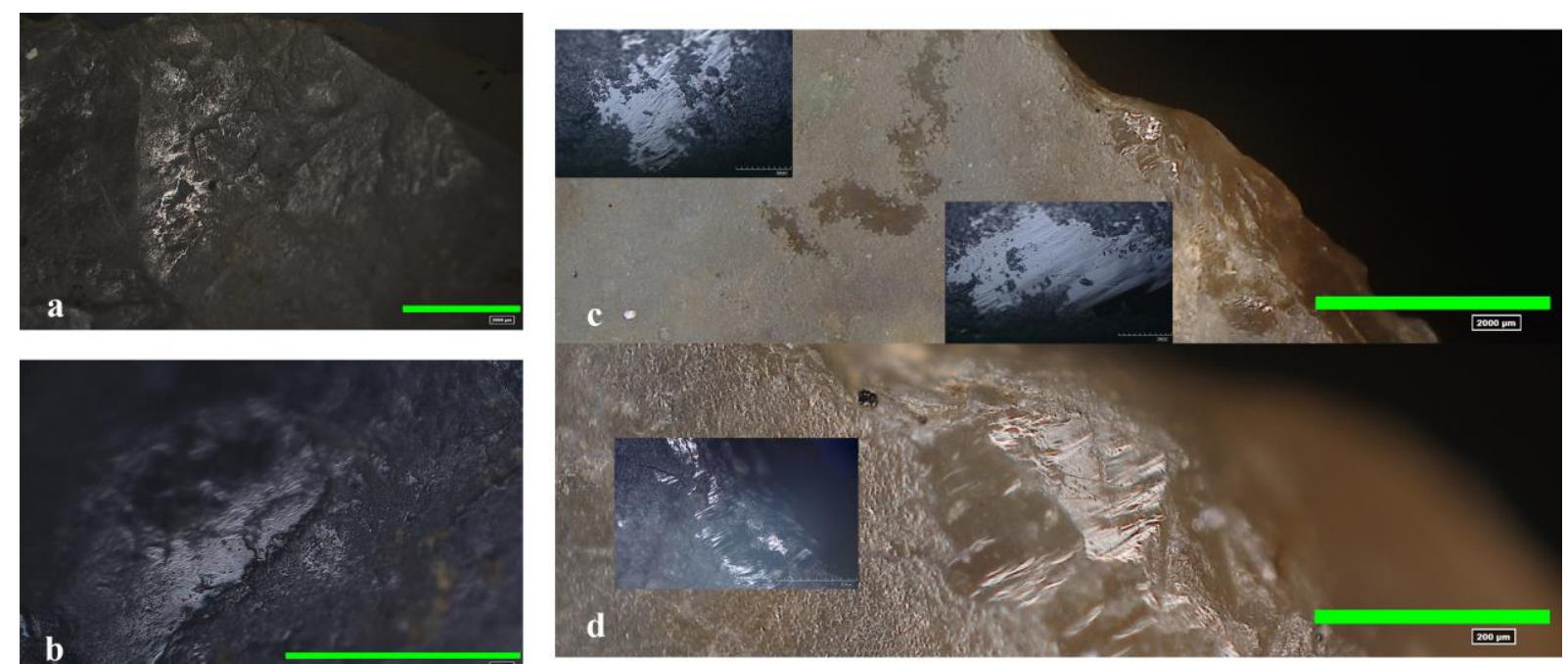

b

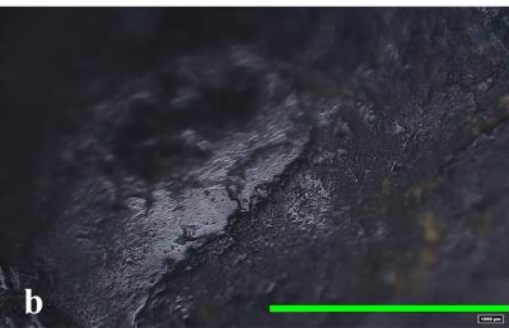

Figure 17. Trench C, sample 36: a) flake, scale bar equal to $2000 \mu \mathrm{m}$ b) flake, scale bar equal to $1000 \mu \mathrm{m}$; Slope 1, sample 24: c) presence of bright spots, scale bar equal to $2000 \mu \mathrm{m} \mathrm{d}$ ) presence of bright spots with and without striations, scale bar equal to $200 \mu \mathrm{m}$. Details of bright spots on c) and d) have scale bars equal to 200 $\mu \mathrm{m}$.

The final group of PDSM observations is represented by numerous cracks, abrasion and rounding (Figure $18 \mathrm{c}, \mathrm{d}$, and e) also with edge removals coming from soil movement and the colluvial deposit (Figure $18 \mathrm{f}$ ). These variables are sometimes very hard to distinguish from use-wear traces, or even from retouch. They are mostly isolated and do not have continuity (Figure $18 \mathrm{e}$ ), their shape is not an indication of the possible hardness of the used material and they look fresh. These kinds of mechanical alterations are not rare, but on a quarry site like Lojanik where a colluvial deposit is present, we can confirm some of the previous doubts about the chipped stone preservation we had before the newly made observations. The postdepositional wear can also be differentiated between the worked flakes and flakes that had gone through mechanical alterations.

\section{Discussion}

As shown before, the reduction sequence of the studied locations is in its initial phase, and most pieces in their advanced stages of reduction seem to be irregular and quite disorganized. The possibility that the lithic technology at the site is very early might be tempting (for example Figure $12 \mathrm{~h}$ ), but that kind of assumption shouldn't be made without further evidence. This kind of technology could have been present in the later periods and 
might have something to do with the activities performed on the quarry. But, what technology can and should tell us is the intentionality of the production, and while some characteristics look quite unorganized or unintentional, others might show some patterns that can be linked to the behavior in certain periods of time, such as the identified Middle Palaeolithic core. The strategy could potentially allow us to look at the different sets of behavior from a different point of view, and understand how the mobility patterns of sedentary or hunter-gatherer group occupants, influenced their activities at the quarry.
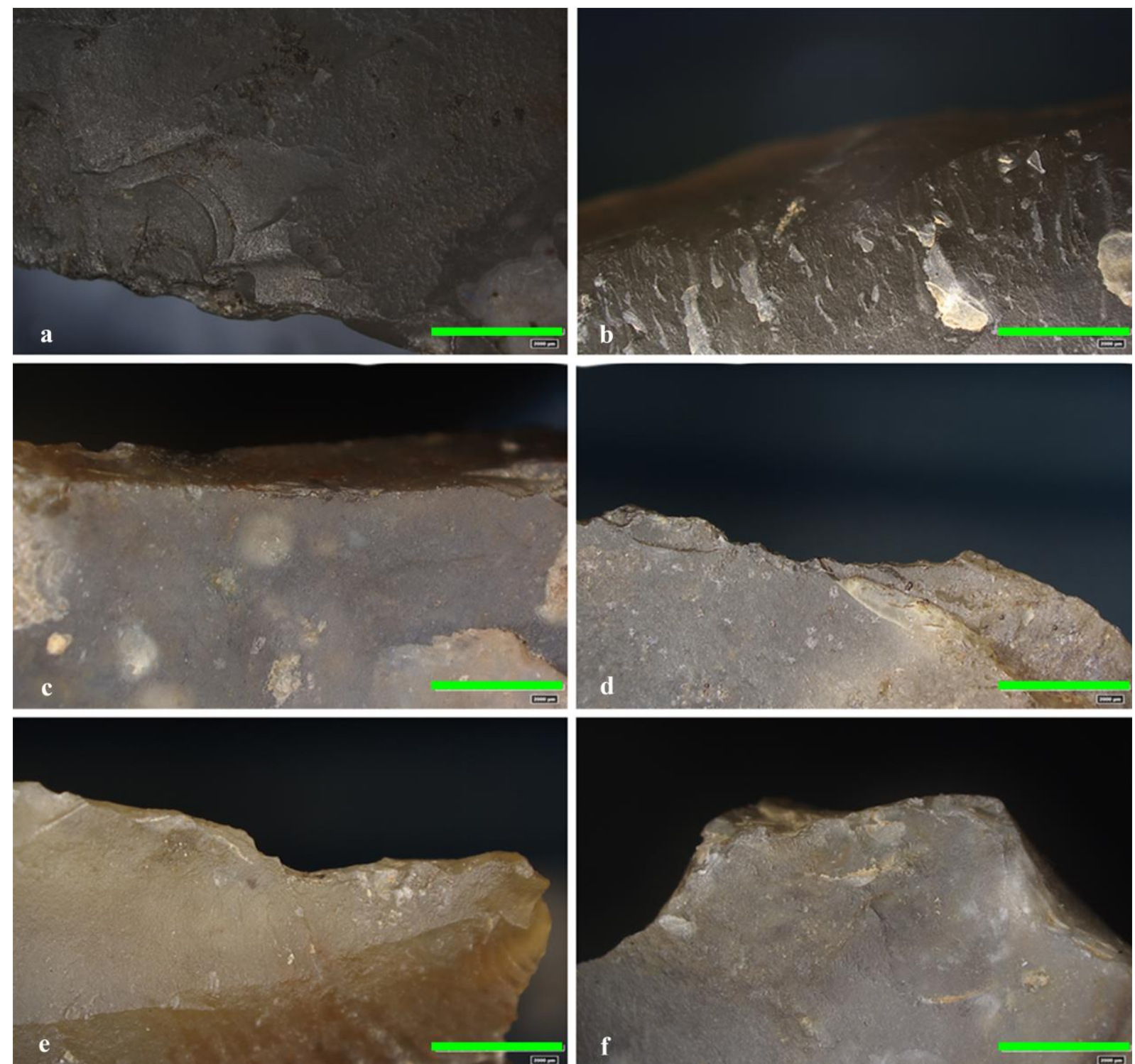

Figure 18. Samples with noted different post-depositional surface modifications like mechanical alterations, trampling, edge rounding, and edge removals not created by use. Trench C, a) sample 36; trench B: b) sample 32; Slope 1: c) sample 24; d) sample 25; e) sample 22, f) sample 27, scale bar equal to $2000 \mu \mathrm{m}$

When talking about the transported material from a geomorphological point of view, the most noted alterations are rounded edges resulted by a prolonged exposure to water. The angular samples evidently were subjected to a shorter transport. Local tectonic movements and climatic changes also influenced processes of natural transport. On some samples, especially if they contained $\mathrm{CaCO}_{3}$ on the surface, submillimeter cavities have been noted, caused by atmospheric dissolving of the carbonates (Figure $12 \mathrm{~g}$ ). 
It is much harder to follow these processes on the silicified rocks. In some cases, when their surface is covered with visible crystals, alteration is manifested by rounded edges of quartz crystals caused by transport of material, via rock on rock friction (Figure $12 \mathrm{e}$ ). Samples that have been through recent burning, or have been exposed to thermal treatment (Figure $12 \mathrm{e}, \mathrm{i}$ ), have no notable surface alterations, but have weak visible unoriented fissures which might have been used to disintegrate the rock itself by hitting it, or exposing it to heat (Figure 12 i). Vitreous samples have most likely been exposed to beating and were desintegrated into pieces of sharp edges in all possible predisposed directions (Figure $12 \mathrm{~b}$ ).

\subsection{Between the two worlds: Pieces in transition}

The object shown in Figure 10 raised many questions - both in the geoarchaeological and technological realms of observation. This fragment of raw material was naturally broken on both sides, creating a flat profile. On one side the artefact is covered in glossy patina showing the natural quality of the local raw material. This was just one of many pieces that we initially could not determine if it was a geofact or an artefact. But a closer look at this piece gave us many answers. Even though the naturally broken surface did not have any pressure or percussion traces or any initiation point whatsoever on one side, three small flake negatives in a row were noticed (Figure 19 a). This location was the beginning of decortifying of the piece. In the same zone a couple of flake negatives are visible going toward the cortex on the side (Figure 19 a), and they were knapped from the cortex surface toward the side flakes, as shown in the figure.
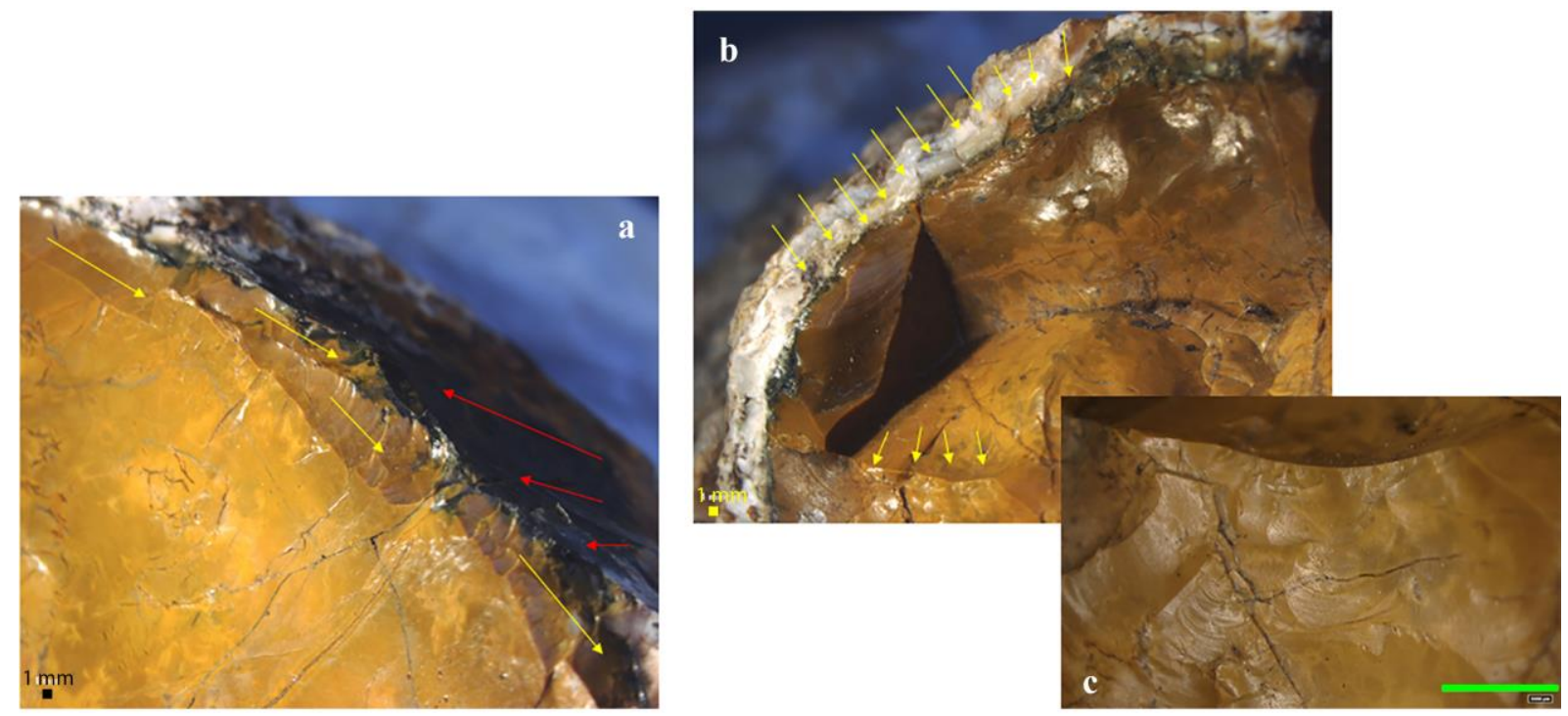

Figure 19. Lojanik 1, Cluster 1, sample 13, possible human extraction of raw material: a) three to four flake negatives from the same direction and three negatives from the cortex to the edge, scale bar equal to $1 \mathrm{~mm} ; b$ ) possible human processing, scale bar equal to $1 \mathrm{~mm} \mathrm{c}$ ) possible human processing (detail), scale bar equal to $2000 \mu \mathrm{m}$.

The other side of the objective piece, shows signs of heavy extraction. Previously, many sharp ridges indicated a natural breakage but if we follow the cortex line on the edges, even though it is heavily weathered and patinated at this point we can notice a lot of percussion initiation (Figure 19 b). Currently we are still unable to precisely define if this piece is a product of human will to extract the blank for a future tool, but we have a lot of evidence for this.

A similar situation is present in the object shown in Figure 12 a (Figure 20). This piece is naturally broken with no initiation or percussion points. In its primary shape, covered with 
cortex, the piece potentially began the reduction process starting from the most ejected edge (Figure $20 \mathrm{~b}$ ). No signs of decertification of this piece are present, but a lot of bright spots and primary reduction activities are noted on this edge. This piece represents one of the forms of thinking of prehistoric societies that frequented Lojanik in the past, it shows their preferences towards the raw material and also the awareness of the quantity of raw materials available in the surroundings.
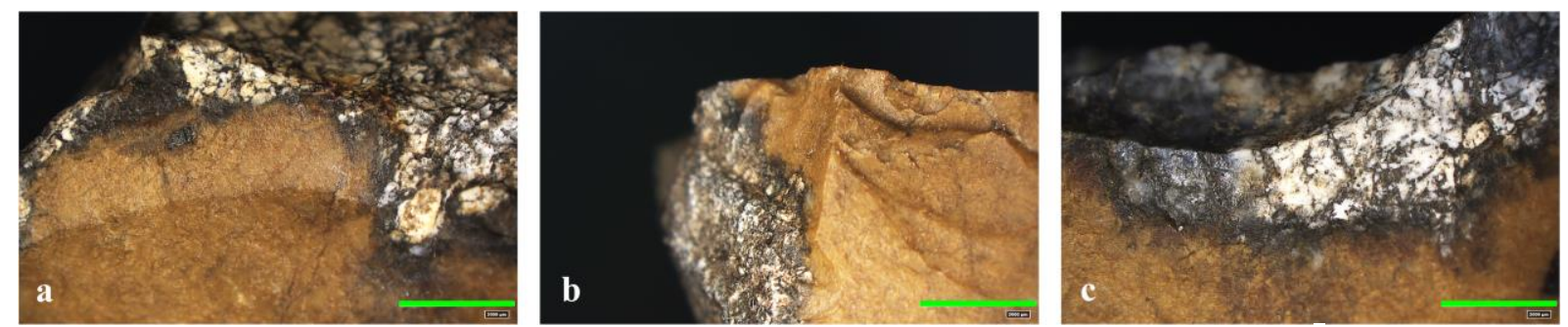

Figure 20. Lojanik 1, Cluster 1, sample 5, fragment of the raw material, scale bar equal to $2000 \mu \mathrm{m}$.

\subsection{Conclusions}

Recognition of the inadequately defined categories of artefacts on the outcrop on Lojanik site are one of the most general and broad conclusions that we achieved during the excavation. At this moment, the conchoidal fracture on the raw material can be interpreted as twofold: deliberate action, or the outcome of random gravitational movement of larger groups of material. This reality has influenced the creation of a combined methodological approach, which was designed to help us obtain the most objective data possible. Petrological, geomorphological and technological analysis of the sample from the mentioned units has been summed up in categories such as worked pieces of raw material, discarded pieces (normally due to inner cracks), shatter and geofact or artefact. This approach has allowed a creation of two categories, natural formations and the anthropogenic ones created by initial outcrop extraction of raw material.

Technological characteristics noted on the Lojanik 2 site will contribute to future research, not just because of the possible Palaeolithic artefacts in their early stages of reduction, but also in the role of the hilltop itself, over this long period of time.

The most notable step which has propelled our research further and introduced other aspects of artefacts from Lojanik is the use of functional analysis. The application of use-wear analysis is not that common in the study of raw material extraction sites, mostly because this kind of sites were not considered to be the places where the tools are used - they were considered to be areas for extraction, testing the raw material, initial shaping and moving the material to the occupational area. The criteria for separating the atrophic from anthropogenic, and the closer look at the grey zone presents a new moment in the study of an artefacts biography. The artefacts found in test-pits are still in the initial phase of their study, but the results have implications for studying the bright spots which are probably formed by mechanical alterations.

Since the excavation methodology is still a work in progress that in the future may help us understand activity at the prehistoric mine sites, we need to allow ourselves to question and test as many possibilities we can and to explore all the ways of creating a valid methodological approach for documenting the extraction of chipped stone raw materials.

\section{Acknowledgments}

This study is the result of the project Lojanik - the Stone Raw Material Mine of Prehistoric Communities in Central Serbia, initiated in 2016 by the National Museum 
Kraljevo, which is being funded by the Ministry of Culture and Information of the Republic of Serbia, no. 119-01-92/2016-02, of 04.05.2016, and Interpretation, Origin and Distribution of Stone Raw Materials from Neolithic and Chalcolithic Sites in the Central Balkans by National Museum in Belgrade. We are very grateful to Cristina Lemorini from the Sapienza University of Rome for suggestions and guidance during microwear observations, and to Boban Tripković from National Museum in Belgrade for technical support of this text.

\section{References}

Andrefsky, William Jr. 2005, Lithics: Macroscopic approaches to analysis. Cambridge Manuals in Archaeology. Cambridge University Press, Cambridge, 301 p. doi:10.1002/gea.20222

Boëda, E. 1993, La débitage discoide et le débitage Levallois recurrent centripède. Bulletin de la Société prehistorique française, 90(6): 392-404. (in French) ("Discoid debitage and recurrent centripede Levallois debitage") doi:10.3406/bspf.1993.9669

Bogosavljević Petrović, V. \& Marković, J. 2014, Raw material studies of west central Serbia. Journal of Lithic Studies, 1: 35-71. doi:10.2218/jls.v1i1.823

Bogosavljević Petrović V. \& Starović, A. 2016, The context of the Early Neolithic in Serbia: Hidden reflections of Mesolithic continuity? Journal of the Serbian Archaeological Society, 32(2016): 7-49.

Bogosavljević Petrović,V., Jovanović, D., Pendić, J. \& Jovanović, D. 2016, Lojanik, westcentral Serbia. Catena of prehistoric mining through time and space. In: Mining and quarrying geological characterisation, knapping processes and distribution networks during pre- and protohistoric times, (Paquet, P., Collet, H. \& Lavachery P., Eds.), 7th International Conference in Mons and Spiennes (Belgium), 28 September - 1 October 2016, Rapports 5 Archéologie. Service public de Wallonie, Spienne: p. 17.

Bogosavljević Petrović, V., Starović, A., Jovanović, D., \& Pendić, J., 2017, Micro-regional quarry-settlement system in the west-central Serbia: Preliminary Lojanik 2016 fieldwork report. Journal of Serbian Archaeological Society, 33: 21-46.

Dibble, H. L., Schurmans, U. A., Iovita, R. P., \& McLaughlin, M. V. 2005, The Measurement and interpretation of cortex in lithic assemblages. American Antiquity, 70(3): 545-560. doi: $10.2307 / 40035313$

Gijn A. 1990, The wear and tear of flint. Principles of functional analysis applied to Dutch Neolithic assemblages. Analecta Praehistorica Leidensia Vol. 22. Publications of the Institute of Prehistory of the University of Leiden, Leiden, $182 \mathrm{p}$.

Glauberman P.J.\&Thorson, R. M. 2012, Flint patina as an aspect of 'flaked stone taphonomy': A case study from the loess terrain of the Netherlands and Belgium. Journal of Taphonomy, 10: 21-43.

URL: https://dialnet.unirioja.es/servlet/articulo?codigo=4983226

Howard C. D. 2002, The gloss patination of flint artifacts. Plains Anthropologist, 47(182): 283-287. doi:10.1080/2052546.2002.11932098

Joksimović, V., Vilotić, D., Šoškić, B. \& Šehovac, E. 1997, Silicified wood at Mataruška Banja (Serbia). In: The 3rd International Conference on the Development of Forestry and Wood Science/Technology, Proceedings Book No. 3, Faculty of Forestry of 
Belgrade University, Serbia, Yugoslavia, Belgrade: p. 383-388.

doi:10.17660/ejhs.2018/83.1.7

Jovanović, B. \& Milić, Č. 1988, Rudnik opala Krivo Polje kod Kragujevca, Zbornik Narodnog muzeja (Čačak), 18: 57-60. (in Serbian) ("Opal mines of Krivo Polje near Kragujevac")

Karamata, S., Dimitrijević, M. D., Dimitrijević, M. N. \& Milovanović, D. 2000, A correlation of ophiolitic belts and oceanic realms of the Vardar Zone and the Dinarides. In: Proceedings of the international symposium "Geology and Metallogeny of the Dinarides and the Vardar Zone” (Eds. Karamata, S. \& Janković, S.), Collections and Monographs Vol. 1. Academy of Sciences and Arts of the Republic of Srpska, Department of Natural, Mathematical and Technical Sciences, Banja Luka/Serbian Sarajevo: p. 61-69.

Keeley L. H. 1980, Experimental determination of stone tool uses: A microwear analysis. University of Chicago Press, Chicago, 226 p.

Levi Sala I. 1986, Use wear and post-depositional surface modification: A word of caution. Journal of Archaeological Science, 13(3): 229-244. doi:10.1016/0305-4403(86)90061-0

Marinčić, S. 2014, Studija zaštite: Spomenik prirode „Lojanik - okamenjena šuma“. (unpublished report). Zavod za zaštitu prirode Srbije, Belgrade, 41 p. (in Serbian) (Protection study: "Lojanik - petrified forest" natural monument)

Marković, B., Urošević, M., Pavlović, Z., Terzin, V., Jovanović, Ž., Vujisić, T. \& Rakić, M., 1968, SFRJ, 1:100.000 Booklet for sheet Kraljevo, K 34-6. Savezni geološki zavod, Belgrade, $66 \mathrm{p}$.

Mihailović, D. \& Bogosavljević Petrović, V. 2009, Samaila - Vlaška Glava, paeolitsko nalazište na otvorenom prostoru, Naša prošlost, 10: 21-44. (in Serbian) ("Samaila Vlaška Glava, open-air Palaeolithic site")

Mihailović, D., Milošević, S., \& Radović, P. 2014, New data about the Lower and Middle Palaeolithic in western Morava valley. In: Palaeolithic and Mesolithic research in the central Balkans, (Ed. Dušan Mihailović), Serbian Archaeological Society, Belgrade: p. 57-68.

Moss E. H. 1983, The functional analysis of flint implements. Pincevent and Pont d'Ambon: Two case studies from the French Final Palaeolithic. BAR International Series Vol. 177, British Archaeological Reports, Oxford, 249 p.

Protić, D. 1995, Mineralne i termalne vode Srbije, Posebna izdanja 17. Geoinstitut, Belgrade, 269 p. (in Serbian) ("Mineral and thermal water of Serbia")

Semenov S. A., 1976, Prehistoric technology: An experimental study of the oldest tools and artefacts from traces of manufacture and wear. Moonraker Press, Bradford-on-Avon, Wiltshire, $211 \mathrm{p}$.

Stapert D. 1976, Some natural surface modifications on chert in the Netherlands. Palaeohistoria, 18: 7-41. URL: https://ugp.rug.nl/Palaeohistoria/article/view/24807

Stevanović, P., Pavlović, M. B. \& Eremija, M. 1977, Čačansko-kraljevački (ili zapadnomoravski basen). In: Geologija Srbije, II-3. Stratigrafija-Kenozoik ( Petković K., Ed.), Institut za regionalnu geologiju i paleontologiju Rudarsko-geološkog fakulteta, Belgrade: p. 270-275. (in Serbian) (“Čačak-Kraljevo (or west Morava) Basin”) 
Šarić, J. 2013, Kremenac, donjopaleolitsko nalazište, Arheološki institut, Belgrade, 178 p. (in Serbian) ("Kremenac, Lower Palaeolithic site")

Vaughan P. 1981, Lithic microwear experimentation and the functional analysis of a Lower Magdalenian stone tool assemblage. PhD Thesis Dissertation, No 8208050. University of Pennsylvania, Philadelphia, $1236 \mathrm{p}$. 